\title{
Telekomünikasyon sektöründe kullanılan ek odası kapaklarının sokak düzeyi görüntülerinden tespit edilme başarımının değerlendirilmesi
}

\author{
Ahmet Eğri ${ }^{1}$ iD, Caner Güney² ${ }^{2}$ (D) \\ ${ }^{1}$ Istanbul Teknik Üniversitesi, Ayazağa Yerleşkesi, Fen Bilimleri Enstitüsü, Sarıyer, Istanbul, Türkiye. \\ 2Istanbul Teknik Üniversitesi, Ayazağa Yerleşkesi, Inşaat Fakültesi, Geomatik Mühendisliği Bölümü, Sarıyer, Istanbul, Türkiye.
}

\begin{abstract}
Öz: Çalışma kapsamında yenilikçi olarak nitelendirilen yöntemle sokak düzeyi görüntülerinden derin öğrenme yaklaşımı ile telekomünikasyon sektöründe kullanılan ek odası kapakları tespit edilmekte ve bu kapakların konum bilgileri üretilmektedir. Sözü edilen yöntemin başarımının değerlendirilmesi için İstanbul ili sınırlarında yer alan ü̧ farklı çalışma bölgesinde elde edilen sonuçlar halihazırda telekomünikasyon sektöründe kullanılmakta olan geleneksel yöntemin sonuçlarıyla karşılaştııılmıştır. Karşılaştırmalı analiz sırasında her iki yöntemle üretilmiş olan ek odası koordinat değerleri arasındaki farklar belirlenmiş, bu farklılıkların nedenleri üzerinde durulmuş ve yapılabilecek iyileştirmelerin neler olabileceği üzerine tartışılmıştır. Elde edilen bulgular ışı̆̆ında yenilikçi yöntemin mevcut durumda doğruluk başarımı özelinde geleneksel yöntemin yerini alamayacağı ve birlikte kullanılmaları durumunda telekomünikasyon sektöründeki uygulamalarda verimliliğin artacă̆ı sonucuna ulaşılmıştır. Bu türden bir yenilikçi yöntemin kullanıldı̆̆ varlı tanımlama ve varlıkların koordinatlarını belirleme çözümlerinde, çalışma kapsamında yapılan önerilerin dikkate alınması durumunda yakın gelecekte yenilikçi yöntemin, geleneksel yöntemin yerine geçeceği öngörülmektedir.
\end{abstract}

Anahtar Sözcükler: Haberleşme, Sokak düzeyi görüntü, Etiketlenmiş mekansal veri, Derin öğrenme, Başarım değerlendirmesi, Mekansal zeka

\section{Evaluation of the performance of detecting the manhole used in the telecommunication sector from the street-level images}

Abstract: Within the scope of the study, with the proposed method, called innovative method, the manholes used in the telecommunication sector are identified with the deep learning approach from the street-level images and location information of these manholes are produced. In order to evaluate the performance of the innovative method, the results obtained with it in three different study regions located within the borders of the city of Istanbul were compared with the results of the traditional method currently used in the telecommunication sector. During the comparative analysis, the differences between coordinate values of the manholes produced by both methods were determined, the reasons for these differences were emphasized and the possible improvements were discussed. According to the findings, it is concluded that the innovative method cannot replace the traditional method in the current situation. However, if both methods are used together, effectiveness and efficiency in the applications in the telecommunications sector will increase. Nevertheless, in the near future, it is anticipated that the innovative method will replace the traditional method if the suggestions made within the scope of the study are taken into consideration in the solutions of detecting the assets and determining the assets' coordinates.

Keywords: Telecommunication, Street-level image, Tagged (geo)spatial data, Deep learning, Performance evaluation, (Geo)Spatial intelligence 


\section{Giriş}

\subsection{Motivasyon}

Telekomünikasyon/haberleşme sektörü teknolojik gelişmeler, kullanıcılarından gelen talepler ve artan beklentilerle birlikte günden güne değişim ve gelişim göstermektedir. Haberleşme sektörünün en önemli bileşenlerinden biri fiber optik altyapıdır. Fiber optik altyapı üzerinden sabit geniş bant internet haberleşmesi tüm dünyada olduğu gibi Türkiye'de de hızla yaygınlaşmaktadır. Telekomünikasyon firmaları yatırım yaptıkları şebeke sistemlerinden maksimum verim elde etmek, kullanıcılarına kesintisiz hizmet sunmak için telekomünikasyon sektörünün bu alanında oldukça yoğun bir rekabet içerisinde bulunmaktadır (Hussain, Kazmi, \& Arsalan, 2017).

Telekomünikasyon hizmetlerinin sürdürülebilmesi için baz istasyonları, saha dolapları gibi yer üstü varlıklar ile borular, boruların içinden geçen kablolar, kabloların birbirine bağlandığı ek yerleri gibi yer altında bulunan varlıklardan yararlanılmaktadır. Fiber optik altyapı yatırımları kapsamında kurulan şebekelerin temel bileşenleri kazı, boru, göz, kablo ve ek odalardan oluşmaktadır. Bu bileşenlerden boru, göz, kablo, vb. varlıklar şebeke kurulumundaki kazı sonrasında yerin altında kalırken, yalnızca ek odası kapakları yer üstünde görülebilmektedir. Haberleşme şebekelerine erişmek, altyapının bakım hizmetlerini gerçekleştirmek, kablolara ekleme yapabilmek için sözü edilen bu ek odalar/ekleme odaları (manhole) kullanılmaktadır.

Haberleşme şebekesi altyapılarının planlanması, yönetilmesi ve son kullanıcıya kadar kesintisiz haberleşme hizmetlerinin sunulabilmesine ilişkin birçok işletim sürecinin etkin ve verimli biçimde yerine getirilebilmesi için Mekansal Bilgi Sistemi (Coğrafi Bilgi Sistemi, CBS; Geospatial Information System, GIS) teknolojisinden yararlanılmaktadır. Bunun için öncelikle fiziksel olarak arazide bulunan yukarıda sözü edilen tüm varlıklar CBS ortamına getirilmekte, sonrasında da topolojik modeller üzerinden mekansal ağ analizleri gerçekleştirilmektedir. Ayrıca, arazide taşınabilir platformlarda bulunan gezgin/hareketli CBS (mobile GIS) uygulamaları kullanılarak operasyonel işlemler de yapılabilmektedir. Özetle büroda yapılan planlamalardan arazide yapılan uygulamalara kadar varlıkların yönetimi ve işletimi bütünsel olarak CBS teknolojisi üzerinden gerçekleştirilebilmektedir. Kısaca ifade edilen bu yaklaşımların ve iş süreçlerinin başarılı biçimde uygulanabilmesi için öncelikle şebekelere ait varlıkların doğru, güvenilir ve düşük maliyetli mekansal veri kümelerinin üretilmesi gerekmektedir.

\subsection{Problem Tanımı}

Telekomünikasyon firmalarının hizmetlerinin sürekliliğini sağlayabilmek için; şebeke sistemlerinde bulunan varlıkların konum bilgilerini doğru bir şekilde üretebilmeleri, altyapı sistemlerinde olan değişikliklerden sonra bu varlıkların konum bilgilerini güncelleyebilmeleri ve yeni eklenen servis uçları nedeniyle genişleyen sisteme eklenen yeni varlıkların konum bilgilerini üretip mevcut sistemle bütünleştirebilmeleri gerekmektedir. Tüm bu ve benzeri işler için telekomünikasyon firmaları önemli miktarda kaynak kullanmakta, yoğun iş gücünden yararlanmakta ve aşırı zaman harcamaktadır.

Her ne kadar yoğun emek ve zaman harcansa da ve CBS tabanlı varlık yönetim sistemlerine önemli yatırımlar yapılsa da, sonuçta uygulamada mekansal veri tabanlarında şebeke varlıklarına ilişkin önemli oranda eksiklikler bulunabilmekte ve yanlışlıklar görülebilmektedir. Şehirlerin genellikle plansız gelişmesi, kentte yaşayan nüfus oranın artması, "akıllı" şehir kavramının uygulamada yer bulması gibi nedenlerle haberleşme altyapılarında ve dolayısıyla şebekelerde sürekli değişim ve gelişim olmaktadır. Bu durum, planlamada kullanılacak olan envanter veri kümelerinin eksiksiz, doğru ve güvenilir özellikte olmasını gerektirmektedir. Doğru planlamalar ve yatırımlar yapabilmek, son kullanıcıların taleplerini ve beklentilerini gecikme olmadan karşılayabilmek için sürekli olarak arazi ölçmeleri yapılarak varlıklara ilişkin konum bilgisinin üretilmesi 
ya da güncellenmesi gerekmektedir (Hebbalaguppe, Garg, Hassan, Ghosh, \& Verma, 2017).

Şebeke varlıklarının mekansal bilgilerinin üretilmesi ve güncellenmesi çalışmalarında oluşan gecikmeler, son kullanıcılara/abonelere daha geç ulaşılmasına neden olmaktadır. Telekomünikasyon firmaları haftalarca sürebilen bu gecikmelerden ötürü önemli ölçüde maddi kayıplar yaşamaktadır. Bu nedenle, yol ağları boyunca uzanan on binlerce kilometrelik şebeke altyapı sistemlerinin genişleme ve bakım faaliyetlerinin yürütülebilmesi için CBS tabanlı varlık yönetim sistemlerinin veri elde edinim ve güncelleme gereksinimlerine hızlı biçimde yanıt verilebilecek çözümlerin geliştirilmesi gerekmektedir.

Telekomünikasyon firmaları varlık yönetim sistemlerindeki veri kümelerini güncellemek ve doğrulamak amacıyla genellikle yılda bir defa olmak üzere periyodik biçimde arazi çalışmaları yapmaktadır. Söz konusu çalışmalarda görevli personel, şebeke envanter bilgi sisteminde yer alan ve arazide tespit edilen varlıkların doğrulama işini genellikle bir gezgin CBS uygulaması kullanarak gerçekleştirmektedir. Şebeke elemanlarında bir değişiklik gözlemlenmesi halinde, ilgili personel bilgi sistemiyle uyuşmazlık olduğunu ifade eden geri bildirimlerde bulunmaktadır. Aylarca sürebilen bu arazi çalı̧̧malarıyla güncellenen veri kümeleri, çalışma süresinin uzun olması nedeniyle çalışma sonunda güncelliğini yitirmiş veri kümeleri haline dönüş̧ebilmektedir. Bununla birlikte, görevli personel tarafindan tek yönlü ve bir kez gerçekleştirilen bu güncelleme ve doğrulama işlerinin güvenilirliği ve doğruluğu da kontrol edilememektedir.

Bunların yanı sıra, telekomünikasyon firmaları fiber optik altyapı yatırım planlamaları yaparken, yüksek son kullanıcı potansiyeline sahip bölgeleri tespit edebilmek için diğer firmaların altyapı veri kümelerine gereksinim duymaktadır. Bir bölge hakkında yatırım kararı alınması sırasında ilgili bölgede diğer firmalara ait altyapının olmaması veya eksik durumda olması gibi bilgiler, karar verme aşamasında yararlanılabilecek en önemli ölçütlerdendir. İlgili bölgeye ilişkin hangi firmaların nerede altyapısı olduğunu gösterir açık kaynaklı veri kümeleri olmadığından dolayı bölgedeki durumun keşfi için yine arazi çalışması yapılması gerekmektedir. Ancak bu tür arazi çalışmaları hem kentin bütününün incelenmesi gerektiği için doğru bölgelerin tespit edilmesinde yetersiz kalmakta hem de sözü edilen arazi çalışmaları firmalara önemli miktarda maliyet oluşturmaktadır.

Yukarıda ifade edilen tüm bu ve benzeri nedenlerden ötürü telekomünikasyon firmaları; arazi çalışmalarıyla büro ortamı arasındaki veri ve bilgi akışını insan faktörüne daha az bağımlı, daha hızlı, daha düşük maliyetle ve daha yüksek veri kalitesiyle sağlayacak bir çözüm arayışı içerisindedir. Böylece telekomünikasyon firmaları zaman ve maliyet giderlerini azaltacak, son kullanıcılarına daha yüksek kalitede hizmet verebilecek ve fiber optik altyapı üzerinden başarılı hizmet sunma rekabetinde öne çıkabileceklerdir.

Çalışma kapsamında fiber optik haberleşme şebekelerinin en önemli düğüm noktalarından olan Şekil 1'de gösterilen ek odalarının konum bilgilerinin üretilmesinde ve güncellenmesinde, geleneksel yöntemle yenilikçi yöntem arasında karşılaştırmalı bir başarım değerlendirmesi yapılacaktır. Bu başarım analizi kapsamında doğruluk, zaman, maliyet gibi farklı ölçütler kullanılacaktır. Her iki yaklaşımla üretilmiş olan ek odası kapaklarının iki boyutlu konum değerleri karşılaştırılacak, mevcut farkların nedenleri analiz edilecek ve ne tür iyileştirmelerin yapılabileceği konularına değinilecektir.

\section{2. İlgili Çalışmalar}

Son y1llarda sokak düzeyi görüntülerini kullanarak farklı tür harita bilgisi üretmeyi amaçlayan çok sayıda çalışma yapılmıştır. Krylov, Kenny, ve Dahyot (2018) yaptıkları çalışmada geliştirdikleri algoritma ile Google Street View platformundaki görüntüleri kullanarak trafik ışıklarının ve telgraf direklerinin konum bilgilerini üretmiştir. Sözü edilen harita bilgileri, bir 
güzergah üzerinde art arda elde edilen görüntülerle kurulan üçgenleme (triangulation) yöntemiyle hesaplanan derinlik mesafesinin görüntülerin elde edildiği konum bilgisiyle ilişkilendirilmesiyle üretilmiştir.

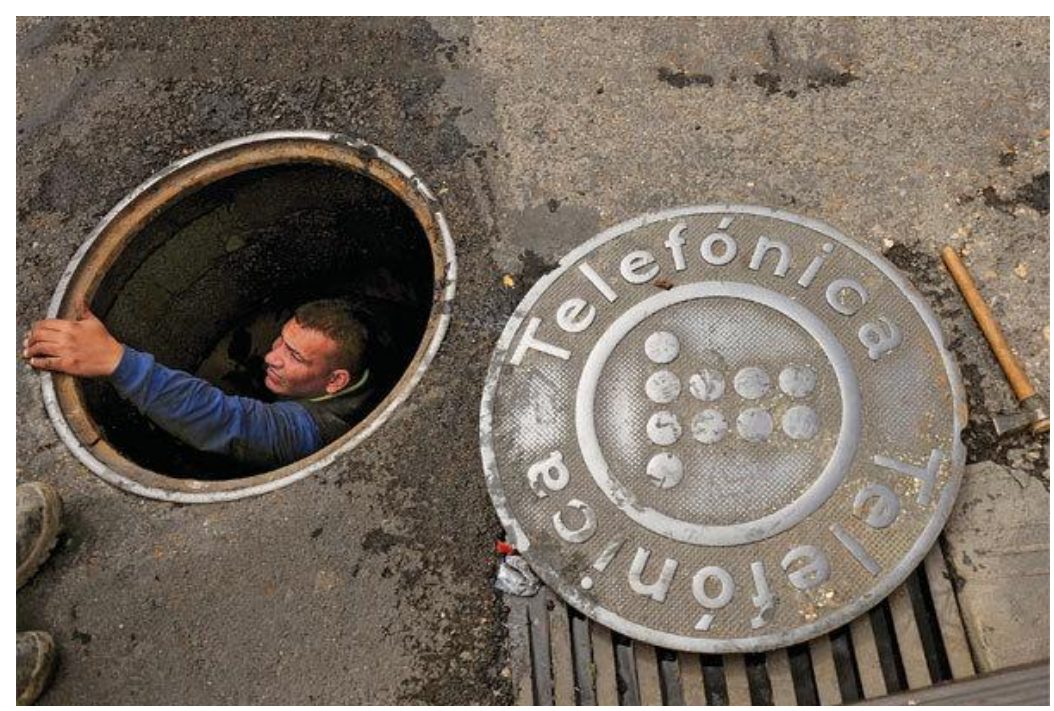

Şekil 1: Ek odası (manhole) örneği (URL-1)

Hebbalagubbe vd. (2017) de yine Google Street View platformundan elde ettikleri görüntülerle ve Krylov vd. (2018)'nin yararlandıkları çözüme benzer şekilde nesne tanımlama yaklaşımını ve üçgenleme tekniğini kullanarak telekomünikasyon sektöründe kullanılan, yer üstünde bulunan varlıklardan olan ek odası, saha dolabı ve baz istasyonu kulesi gibi nesnelerin konum bilgilerini üretmişlerdir.

Akademik çalışmaların yanı sıra benzer konularda farklı firmaların geliştirdiği farklı çözümler de bulunmaktadır. 2009 yılında OpenStreetView adıyla başlayan, 2016 yılında Telenav firması, 2019 yılında Grab firması tarafından satın alınan ve OpenStreetCam olarak yeniden isimlendirilen projeyle sokak düzeyi görüntülerden nesne tanımlama yaklaşımı kullanılarak trafik işaretleri ve trafik 1şıkları tespit edilebilmektedir. OpenStreetCam platformunun temel amacı navigasyon uygulamalarında gereksinim duyulan hız limitleri ve dönüş kısıtlamalarına yönelik harita bilgilerinin sokak düzeyi görüntüler kullanılarak üretilebilmesidir.

Benzer biçimde Türkiye'de DECE firmasının GEODI 360 uygulaması araç kamerası veya cep telefonuyla elde edilen görüntülerden trafik işaretleri ve rögar kapakları gibi nesnelere ait mekansal veri kümelerini üretebilmektedir.

Çalışma kapsamında sokak düzeyi görüntülerden telekomünikasyon sektöründe kullanılan ek odası kapaklarının tespit edilmesi ve konum bilgilerinin üretilmesi için OpenStreetMap (OSM) projesine de destek veren Mapillary firmasının Mapillary platformunun yapay öğrenme temelli nesne tanımlama çözümünün kullanılması tercih edilmiştir. Böylece, çalışma kapsamında elde edilmiş olan sokak düzeyi görüntüler OSM projesinin veri iyileştirmesine katkı sunmak amacıyla da kullanılmıştır. 2019 yılında yapay zeka platformunu OSM kullanımına açan Facebook; Google, Apple, Yandex gibi firmaların GoogleStreetView gibi ürünleri ile rekabet edebilmek için Mapillary platformunu 2020 yılının Haziran ayında bünyesine katmıştır.

\section{Yöntem}

Çalışma kapsamında geleneksel ve yenilikçi olarak isimlendirilen iki farklı yöntem İstanbul sınırları içerisinde Kadıköy ilçesinde bulunan Feneryolu Mahallesi, Ataşehir ilçesinde yer alan Küçükbakkalköy Mahallesi ve Silivri ilçesine bağlı Yeni 
Mahalle olmak üzere üç farklı çalışma alanında uygulanmıştır. Sözü edilen çalışmalar kapsamında her iki yöntemle elde edilen veri kümeleri aşağıda ayrıntılı biçimde ifade edildiği biçimlerde karşılaştırılmıştır.

\subsection{Geleneksel Yöntemle Mekansal Verinin Elde Edilmesi ve Değerlendirilmesi}

Telekomünikasyon firmaları halihazırda mekansal verinin üretilmesinde, değerlendirilmesinde ve varlık yönetiminde kullanılmasında geleneksel yaklaşımdan yararlanmaktadır. Sözü edilen geleneksel yaklaşımın iş akışı ana hatlarıyla Şekil 2'de gösterilmektedir.

Geleneksel yöntemde arazi personeli tarafından jeodezik ölçme yöntemleri uygulanarak ek odası kapaklarının konum bilgileri üretilmektedir. Ardından, ölçmesi yapılan varlığa ilişkin öznitelikler kayıt edilmektedir. Son olarak, büro ortamında konum bilgisi ve öznitelik bilgileri bütünleştirilerek CBS ortamında oluşturulmuş olan mekansal modele aktarılmaktadır. Bu işlemler şebeke altyapısının genişlemesi ya da bakım ve yenileme kapsamında şebekeye yeni varlıkların eklenmesi durumunda tekrarlanmaktadır.

Jeodezik ölçme işlemi, temel olarak Global Uydu Navigasyon Sistemi (Global Navigation Satellite System, GNSS) gözlemleri kullanılarak Şekil 3 (a)'da gösterildiği biçimde uygulanmaya çalışılmaktadır. Uydudan gelen sinyallerin sağlıklı bir şekilde alınamadığı sık ve yüksek yapılaşmanın yoğun olduğu bölgelerde yersel ölçme teknikleri kullanılmaktadır.

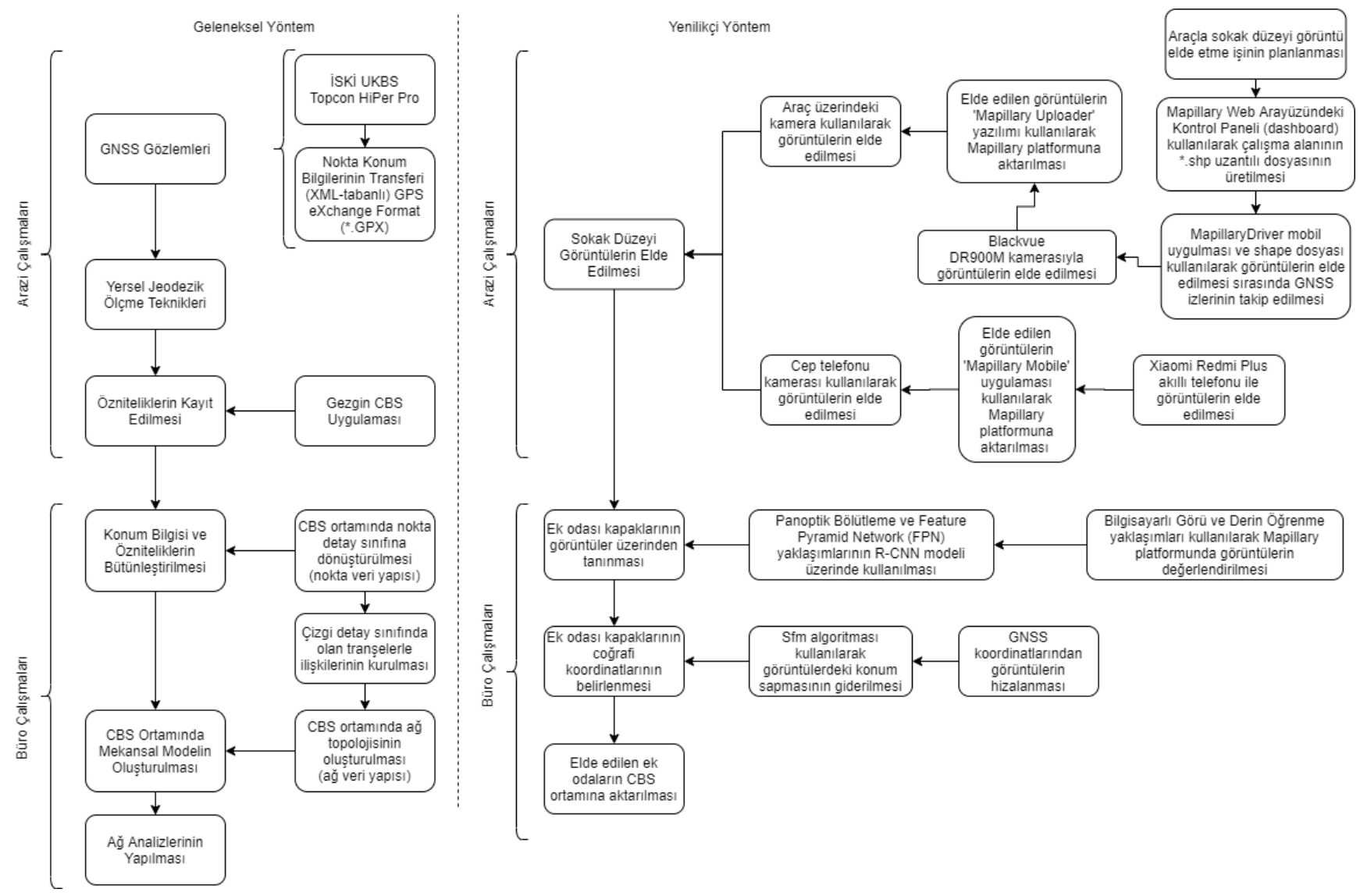

Şekil 2: Geleneksel ve yenilikçi yöntemlerin iş akışları

Çalışma kapsamında referans (ground truth) olarak kullanılan noktaların üç boyutlu konum bilgileri; sürekli gözlem yapan GNSS istasyonlarından (Continuously Operating Reference Stations, CORS) oluşan İstanbul Su ve Kanalizasyon İdaresi Uydularla Konum Belirleme Sistemi’ne (İSKİ-UKBS) bağlı olarak Gerçek Zamanlı Kinematik (Real-Time Kinematic) ölçme tekniği uygulanarak üretilmiştir. Gezici GNSS alıcısı olarak Trimble firmasının çift frekanslı R6 alıcısı ile Topcon firmasının 
Hiper Pro GNSS alıcısı kullanılmıştır. Feneryolu ve Küçükbakkalköy Mahalleler'inde gerçek zamanlı GNSS gözlemleri 2019 yılının Ağustos ayında, Yeni Mahalle'de ise 2020 yılının Mayıs ayında gerçekleştirilmiştir. Tablo 1'de görüldüğü üzere çalışma kapsamındaki toplam 178 ek odası 9 günde toplam 70 saatlik bir çalışma süresiyle ölçülmüştür. GNSS gözlemleriyle gerçek zamanlı olarak elde edilen ek odası kapaklarının orta noktalarının koordinat değerleri CBS ortamına aktarılarak nokta veri yapısına dönüştürülmüştür.

a)

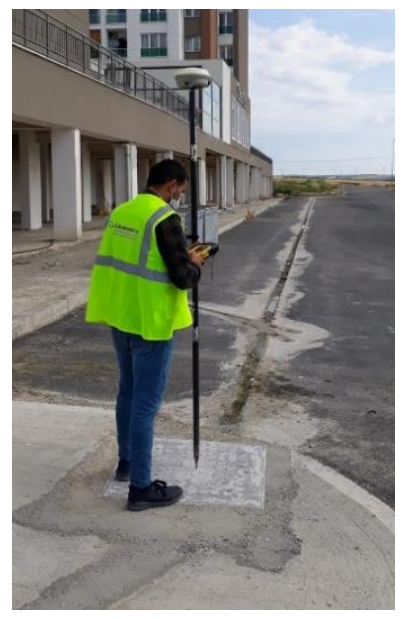

b)

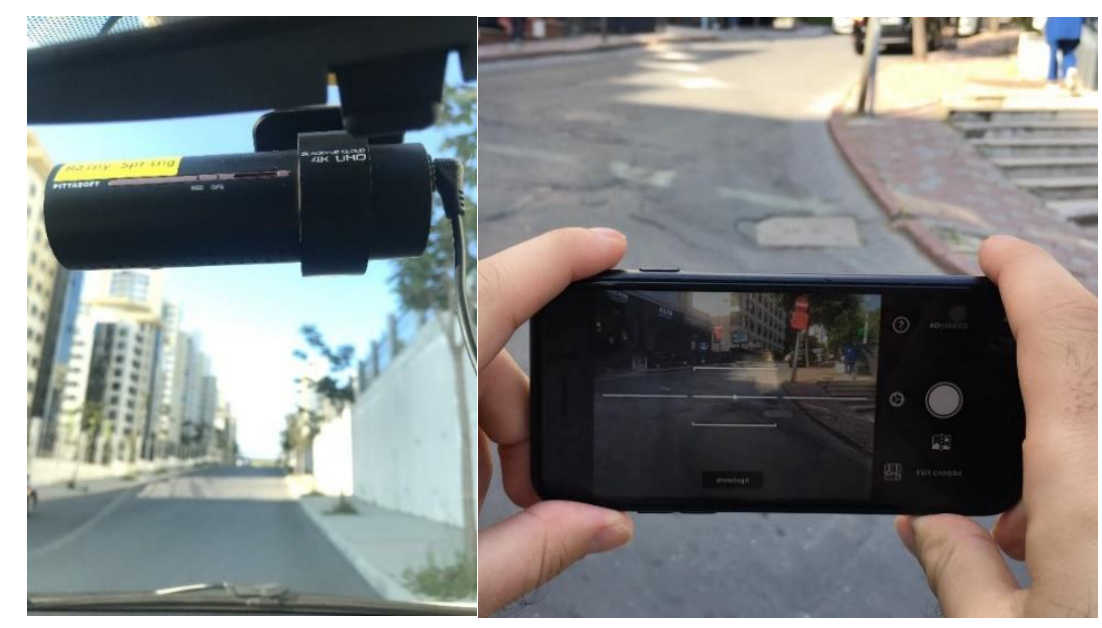

Şekil 3: Geleneksel (a) ve yenilikçi (b) yöntemlerle veri üretiminin uygulama örneği

Tablo 1: Geleneksel yöntemin uygulanış bilgileri

\begin{tabular}{cccccc}
\hline Çalışma Bölgesi & $\begin{array}{c}\text { GNSS Gözlem } \\
\text { Tarihi }\end{array}$ & $\begin{array}{c}\text { GNSS Tekniği ile } \\
\text { Ölçülen Ek } \\
\text { Odası Sayısı }\end{array}$ & $\begin{array}{c}\text { GNSS Gözlem } \\
\text { Süresi }\end{array}$ & $\begin{array}{c}\text { Arazideki Ölçme } \\
\text { Operatörü Sayısı }\end{array}$ & Ölçme Maliyeti \\
\hline Feneryolu & Ağustos 2019 & 58 & 3 gün (25 saat) & 2 & $5000.00 \mathrm{TL}$ \\
\hline Küçükbakkalköy & Ağustos 2019 & 45 & 2 gün (15 saat) & 1 & $4000.00 \mathrm{TL}$ \\
\hline Yeni Mahalle & Mayıs 2020 & 75 & 4 gün (30 saat) & 1 & $7000.00 \mathrm{TL}$ \\
\hline Toplam & & $\mathbf{1 7 8}$ & $\mathbf{9}$ gün (70 saat) & & $\mathbf{1 6 ~ 0 0 0 . 0 0 ~ T L}$ \\
\hline
\end{tabular}

\subsection{Yenilikçi Yöntemle Mekansal Verinin Elde Edilmesi ve Değerlendirilmesi}

Çalışma kapsamında tanımlanan problemin çözümü için önerilen ve yenilikçi olarak nitelendirilen yöntem, ek odası kapaklarının sokak düzeyi görüntüler (street-level images) üzerinden bilgisayarlı görü yaklaşımı ve derin öğrenme modelleri kullanılarak otomatik olarak tespit edilmesi ve konum bilgilerinin üretilmesidir. Başka bir ifadeyle, yenilikçi olarak nitelendirilen yöntem önceden eğitilmiş yapay öğrenme modellerinin kullanılmasıyla (execution of pre-trained models) makine tarafından harita bilgisinin (machine-generated map data) oluşturulmasıdır. Yöntemin iş akışı genel olarak Şekil 2’de verilmiştir.

Yenilikçi yöntem kapsamında sokak düzeyi görüntülerinin elde edilmesinde iki farklı teknik kullanılmıştır. Bunlardan ilki uygulama örneği Şekil 3(b)'de gösterildiği gibi olan araç üzerinde bulunan kamera ile araç hareket halindeyken görüntülerin kayıt edilmesidir. Diğer teknik ise bir veri üreticisinin yolda yürürken akıllı telefon kamerası ile yaptığı görüntü kaydıdır. Yenilikçi yöntem kapsamında iki farklı tekniğin kullanılmasının nedeni aynı değerlendirme yaklaşımı kapsamında farklı görüntü elde etme tekniklerinin de başarımlarının karşılaştırılabilmesine olanak sağlamaktır. Her iki teknikle elde edilen görüntüler Mapillary platformunda bulunan tek bir derin öğrenme modeli kullanılarak birlikte değerlendirilmiştir.

Mapillary platformu toplum/kitle kaynak (crowdsourcing) yöntemiyle kullanıcılardan sokak düzeyi görüntüleri toplayıp, bu görüntülerden derin öğrenme yöntemiyle trafik ışıkları, trafik levhaları gibi vektör veri yapısında ilgi noktası (Point-ofInterest, POI) özellikli harita bilgilerinin üretildiği bir girişim (start-up) çözümüdür (Ertler vd. 2019; Neuhold, Ollmann, Rota 
Bulo, \& Kontschieder, 2017; URL-2).

Araçla sokak düzeyi görüntülerin elde edilmesinde araç kamerası (dash cam) olarak Blackvue markasının DR900M kamerası kullanılmıştır. Araçta kullanılan DR900M kamerası 160 geniş açılı lensiyle, 8 megapiksel çözünürlüklü CMOS sensörüyle 4K kalitesinde (3840x2160p@ 30 fps) görüntü kaydedebilmektedir. Blackvue ve Mapillary firmaları arasında yapılan anlaşma gereğince Mapillary firmasına özel olarak üretilmiş olan bu kamerada; görüntüleri elde edildikleri andaki koordinat bilgisi ile ilişkilendiren özel bir yazılım bulunmaktadır. Görüntülerin elde edildikleri andaki konum bilgileri kamera ile bütünleşik olarak çalışan GNSS alıcısı ile üretilmektedir. Araç üzerinde elde edilen görüntüler bir masaüstü yazılım olan Mapillary Uploader kullanılarak Mapillary platformuna aktarılmaktadır.

Araç kamerasıyla sokak düzeyi görüntülerin elde edilmesinin planlanması sırasında Mapillary firmasının web-tabanlı arayüzü (https://www.mapillary.com/drive) üzerinden erişilebilen kontrol paneli kullanılarak çalışma bölgesinin sınırları belirlenmiş ve *.shp uzantılı dosya olarak bu planlama kaydedilmiştir. Şekil 4’te Feneryolu Mahallesi için yapılmış olan planlama örneği görülmektedir. Üretilmiş olan *.shp uzantılı dosya, araçla görüntülerin elde edilmesi aşamasında MapillaryDriver mobil uygulamasında açılarak GNSS izleri sayesinde görüntü alınan güzergahların takip edilebilmesini ve böylece görüntü elde etme işinin yönetilmesini sağlamaktadır.

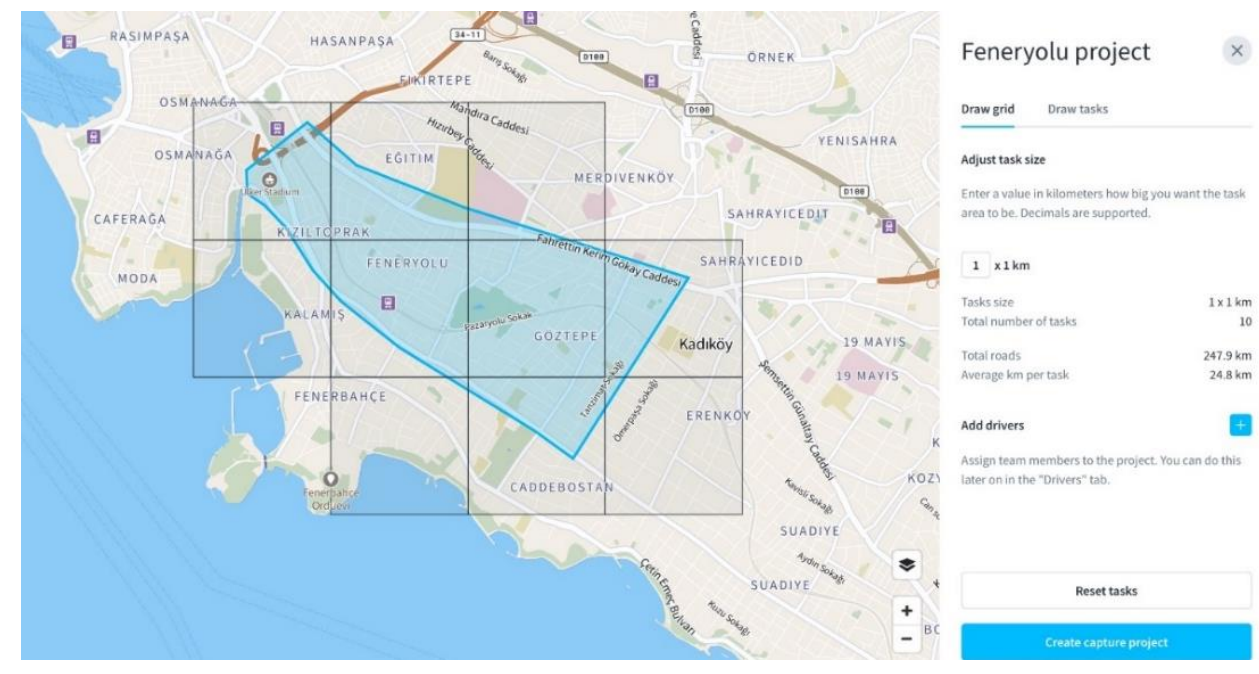

Şekil 4: Mapillary web arayüzünde Feneryolu Mahallesi çalışma alanının tanımlanması

Yürürken akıllı telefon kamerasıyla görüntü kaydetme tekniğinin uygulanması sırasında Mapillary Mobile uygulaması kullanılmıştır. Bu uygulama ile hem görüntü kaydı hem de Mapillary platformuna görüntülerin aktarımı yapılabilmektedir. Görüntüler ayrıca akıllı telefonun dahili hafızasına da kayıt edilebilmektedir. Çalışma kapsamında Xiaomi markasının Redmi 5 Plus modeli akıllı telefonu kullanılarak sokak düzeyi görüntüler kayıt edilmiştir. Xiaomi Redmi 5 Plus akıllı telefonunda bulunan kameranın çözünürlüğü 12MP olup 4K kalitesinde (2160p@30 fps) görüntü kaydedebilmektedir. Şekil 5’te Ataşehir ilçesi Küçükbakkalköy Mahallesi’nde Mapillary Mobile uygulamasının kullanımına ilişkin ekran görüntüsü görülmektedir.

İki farklı yaklaşımla elde edilen sokak düzeyi görüntüleri Mapillary platformuna aktarıldıktan sonra Mapillary tarafından geliştirilmiş olan yapay öğrenme algoritmasının ek odaları tahmin etme doğruluğunun arttırılması için doğrulama (verification) çalışması Mapillary firması tarafından başlatılmıştır. Tüm dünyadan ilgi gösteren herkesin katılımına açık olan doğrulama çalışması, derin öğrenme modelinin özellikle ek odası kapaklarını tanıma başarımının arttırılması için modelin eğitimine katkıda bulunulmasına olanak sağlamaktadır. Şekil 6'da gösterildiği üzere uygulama; doğrulama çalışmasına katılan kullanıcılara, derin öğrenme sınıflandırıcısının ek odası olarak tanımladığı (recognition) nesneleri kare içerisine alarak 
doğru tahmin yapılıp yapılmadı̆̆ını sormaktadır.

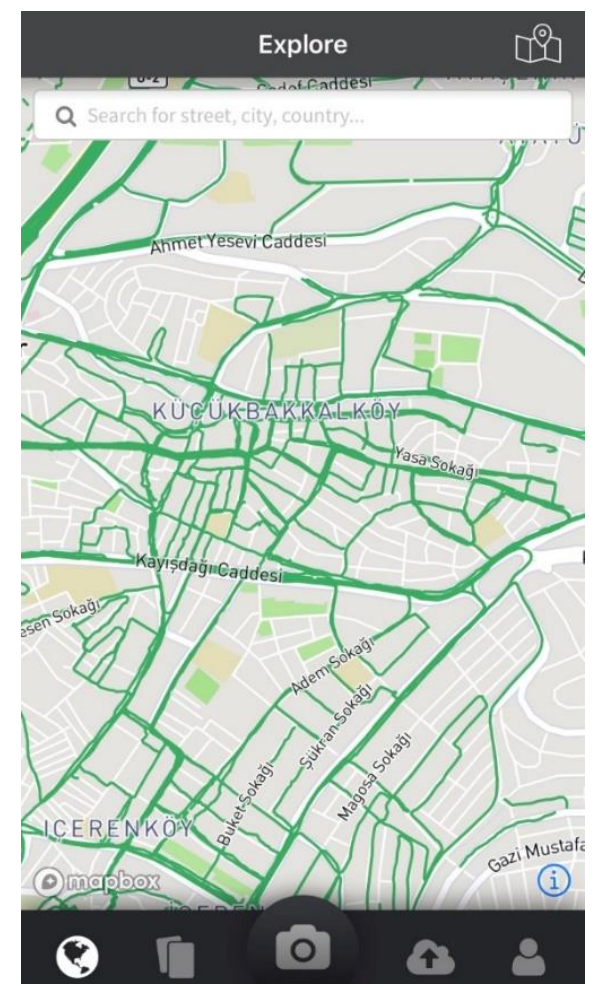

Şekil 5: Mapillary mobil uygulamasının arayüzü

$\mathrm{Bu}$ çalışma kapsamında üretilmiş olan görüntülerin de içinde bulunduğu tüm İstanbul'a ait veri kümesine ilişkin olarak algoritma tarafından içinde ek odası olma ihtimali bulunan 254694 görüntü tespit edilmiştir. Şekil 7'de görüldüğü üzere 25 farklı gönüllü kullanıcının Mapillary Verifier Tool arayüzü üzerinden katıldığı veri doğrulama sürecinde, gönüllü kullanıcılar tarafından 254694 görüntü arasından 5134 adet görüntüde ek odası kapaklarının doğru tespit edildiği ve 4413 görüntüde ise ek odası kapağı bulunmadığı belirlenmiştir (URL-3).

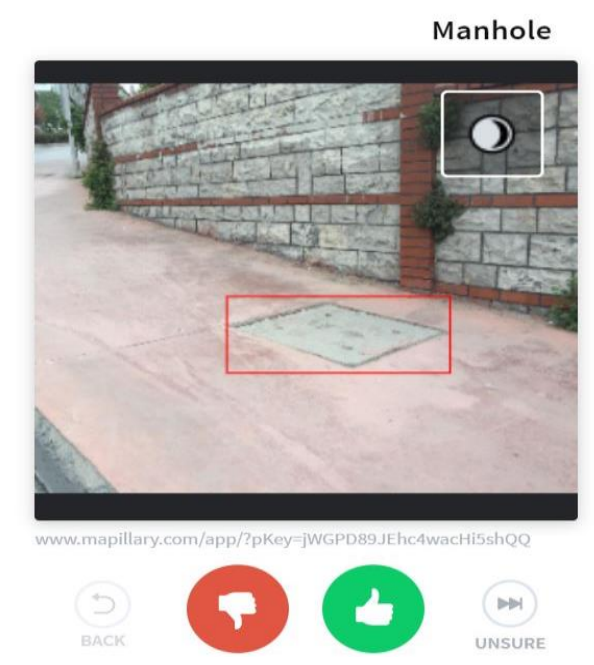

Şekil 6: Mapillary nesne doğrulama arayüzü

Mapillary platformunda görüntü üzerinden derin öğrenme modeli ile tespit edilen nesnelerin gerçek dünyadaki konum bilgileri, ilgili görüntülerin elde edildiği andaki kamera konumu ile doğrudan ilişkilidir. Çalışma kapsamında görüntülerin elde edildiği araç kamerası ve akıllı telefon kamerası bu nedenle gömülü GNSS alıcıları ile birlikte bütünleşik yapıda kullanılmıştır. Ancak hem sözü edilen donanımlarda gömülü biçimde bulunan GNSS alıcılarının konum bilgisi üretme 
doğruluğunun jeodezik ölçme için üretilmiş GNSS alıcılarına göre düşük olması, hem de kent içinde, özellikle yüksek ve yoğun yapılaşmanın olduğu bölgelerde GNSS sinyallerinin kalitesinin azalmakta olması, görüntü elde etme anında üretilen konum bilgisinin kalitesini kötüleştirmektedir. Bu nedenle Mapillary platformu görüntülerin elde edildiği anda bozulan konum bilgi doğruluğunu iyileştirmek için Hareket ile Nesne Oluşturma (Structure from Motion, SfM) algoritmasından yararlanmaktadır. Geleneksel fotogrametrik yöntemlere göre daha hızlı ve düşük maliyetli olan insansız hava aracı fotogrametrisinde (drone photogrammetry) yaygın olarak kullanılan SfM algoritması, art arda gelen görüntü dizileri arasında yanlış hizalanmış olanların doğru konuma getirilmesine yardımcı olmaktadır (Schonberger ve Frahm, 2016; Ullman, 1979). Böylece görüntü üzerinde tespit edilen nesnelerin coğrafi konumları daha yüksek doğrulukla belirlenebilmektedir. Şekil 8'de kırmızı noktalar GNSS gözlemleri ile elde edilen görüntü elde etme konumlarını, yeşil noktalar ise Mapillary platformunda OpenSfM kütüphanesi (URL-4) kullanılarak mevcut yol ağına doğru yönlendirilmiş noktaları göstermektedir. GNSS tekniği ile elde edilen konumlara göre oluşturulan modele SfM algoritmasının uygulanması Şekil 8'de görüldüğü üzere gerçekliğin daha doğru temsil edilmesini sağlamaktadır.

\begin{tabular}{|lrr|}
\hline Manhole & Go to task & Hide \\
Not verified yet & 254694 & $96.20 \%$ \\
Verifications pending & 504 & $0.19 \%$ \\
Verified detections & & \\
\hline Confirmed & 5134 & $1.94 \%$ \\
\hline Rejected & 4413 & $1.67 \%$ \\
\hline Total detections in project & & \\
\hline
\end{tabular}

Şekil 7: Ek odası tahminlerinin doğrulama çalışması sonuçları

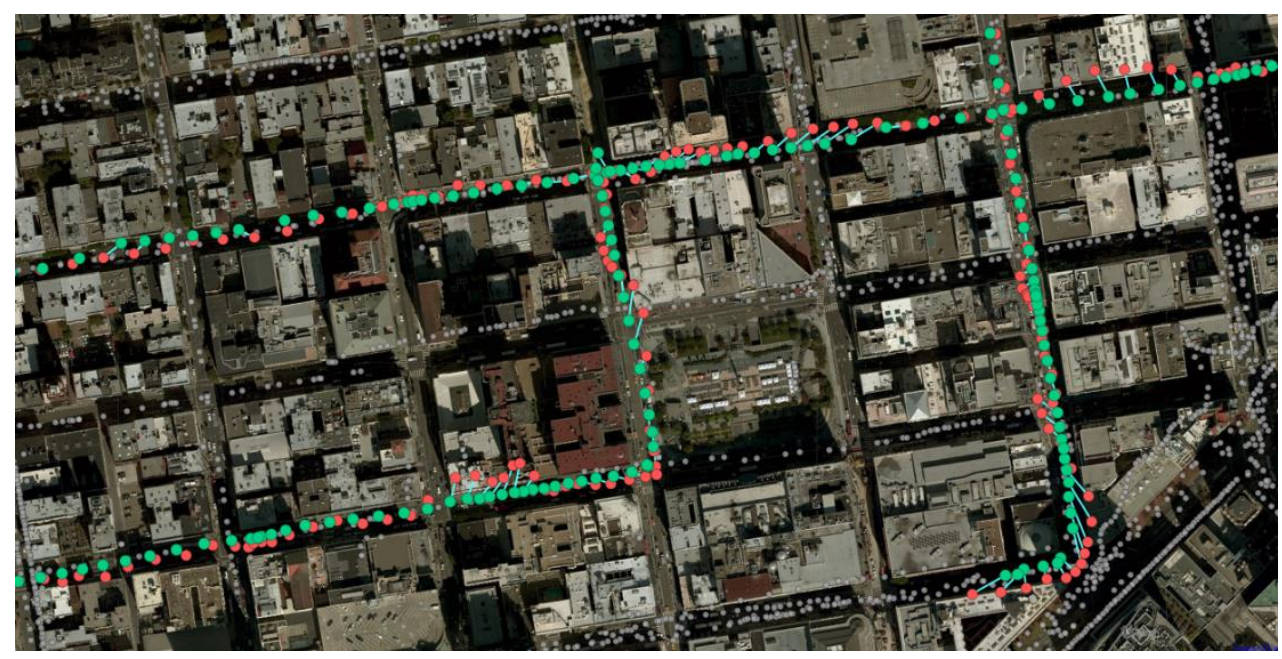

Şekil 8: Görüntülerin elde edildiği konumların kalitesinin Mapillary platformunda iyileştirilmesi

Düşük maliyetli bir bilgisayar görüsü algoritması olan SfM, kalibrasyonu yapılmamış kameralarla farklı açılardan belirli örtü alanına sahip olacak biçimde yani stereo fotogrametri yaklaşımıyla elde edilen iki boyutlu görüntülerden, görüntüde yer alan nesnelerin 3 boyutlu (3B) grafik modellerinin oluşturulmasını sağlamaktadır. Başka bir ifadeyle farklı zamanlarda, rastgele dizilimde elde edilen görüntüler, eğer belirli bir oranda çakışıyorlarsa/örtüşüyorlarsa SfM yaklaşımı kullanılarak 3B grafik model üretilebilir. Geleneksel fotogrametrik teknikler geometrik model oluşturabilmek için, kamera ve yer kontrol 
noktalarının 3B konum ve dönüklük bilgilerine gereksinim duyarken, SfM algoritmasında kamera konum ve dönüklük bilgileri model geometrisinin oluşturulmasıyla aynı anda ve otomatik olarak çözülmektedir. Bu durumda 3B grafik model oluşturmak için yer kontrol noktalarına da gereksinim bulunmamaktadır (Dellaert, Seitz, Thorpe, \& Thrun, 2000; Fonstad, Dietrich, Courville, Jensen, \& Carbonneau, 2013; Snavely, 2008; Snavely vd., 2008).

SfM yaklaşımının ilk adımı farklı görüntülerin örtü alanlarında bulunan aynı nesnelerin Scale Invariant Feature Transform (SIFT) algoritması (Lowe, 2004) kullanılarak belirlenmesidir. Örtü alanlarında bulunan nesnelerdeki ortak detaylar (feature) belirlendikten sonra, sözü edilen bu detaylar kamera koordinatlarının ve seyrek nokta bulutu biçiminde sahne geometrisinin oluşturulmasında kullanılır. RANdom SAmple Consensus (RANSAC) (Fischler \& Bolles, 1981) gibi bir algoritma ve derinlik bilgisini ortaya çıkaran üçgenleme tekniği kullanılarak ortak noktaların en az 3 resim üzerinde iki farklı üçgen oluşturmasıyla görüntü uzayında noktaların koordinatları belirlenir. Bu yaklaşımlarla tüm görüntüler hizalandıktan ve tüm görüntülere ait kamera konum bilgileri ortaya çıkarıldıktan sonra sahnenin yeniden ve daha kaliteli oluşturulması için görüntülerden yoğun nokta bulutu oluşturulur (Snavely, 2008; Snavely vd., 2008). Sahneye ilişkin geometrik model olarak nokta bulutu oluşturulduktan sonraki aşamalar mesh modelin oluşturulması ve mesh modelin doku ile kaplanmasıdır.

Ortaya çıkan 3B grafik model belirli bir iç doğrulukta görüntü uzayı koordinat sisteminde bulunmaktadır. Araç üzerinde bulunan GNSS alıcılarının görüntü kaydı sırasında ürettiği konum bilgileri kullanılarak 3B model coğrafi koordinat sistemine getirilebilmekte ve coğrafi referanslı bir mesh model oluşturulmuş olmaktadır.

Temel veri kaynağının sokak düzeyi görüntüleri olması nedeniyle SIFT algoritmasının dolayısıyla SfM algoritmasının başarımı; görüntüleri elde etmek için kullanılan kameranın özellikleri, görüntü çözünürlüğü, görüntü sayısı/yoğunluğu, gün 1şığının aydınlatma durumu, çekim açısı gibi birçok etkene bağlı bulunmaktadır. Sonuç olarak tüm bu etkenler sokak düzeyi görüntülerinden ortaya çıkarılacak olan nokta bulutunun yoğunluğunu ve doğruluğunu etkilemektedir.

\subsection{Yenilikçi Yöntemin Başarım Analizi}

Üç farklı bölgede iki farklı yöntemle gerçekleştirilen çalışmalarla yenilikçi yöntem olarak nitelendirilen yöntemin başarım değerlendirmesi konum doğruluğu, veri değerlendirme süresi, üretim maliyeti gibi farklı açılardan karşılaştırılmalar yapılarak gerçekleştirilmiştir.

\subsubsection{Yenilikçi Yöntemle Tespit Edilen Ek Odası Kapaklarının Tanımlama Başarımının Değerlendirilmesi}

Sınıflar arasındaki dağılımın yakın olmaması nedeniyle çalışma kapsamında kullanılan yapay öğrenme modelinin başarımını yalnız doğruluk (accuracy) ölçütü ile değerlendirmek yeterli olmayacaktır. Bu nedenle doğruluk ölçütünün yanı sıra, hassasiyet (precision) ve duyarlılık (recall) gibi diğer ölçütler de başarımı değerlendirmek için dikkate alınmıştır. Bunun için öncelikle yapay öğrenmede sınıflandırma problemlerinde kullanılan, gerçek değerlerle (actual values) tahmin edilen değerler (predictive values) arasındaki ilişkileri gösteren Doğru Pozitif (True Positive, TP), Yanlış Pozitif (False Positive, FP), Doğru Negatif (True Negative, TN), Yanlış Negatif (False Negative, FN) metriklerinden oluşan bir çapraşıklık matrisi (confusion matrix) oluşturulmuştur. Çapraşıklık matrisi, gerçek ve tahmin edilen değerlerle oluşturulan 4 farklı birleşimli bir tablodur. Geleneksel yöntem sonuçlarının referans veri alınarak, yenilikçi yöntemle üretilen sonuçların referans kümesiyle olan ilişkilerine göre sözü edilen metriklerin değerleri CBS ortamında belirlenmiştir. Şekil 9-11'de her üç bölge için CBS ortamında yapılan çalışmaların sonucunu, diğer bir ifadeyle yenilikçi yöntemle tahmin edilmiş olan ek odaların sözü edilen dört metriğe göre sınıflandırılmasını gösteren tematik haritalar bulunmaktadır. Tablo 2'de her üç çalışma bölgesine ait örnekleme veri kümeleri için oluşturulmuş çapraşıklık matrisleri verilmektedir. Çalışma amacı göz önünde bulundurularak sözü edilen metrikler aşağıdaki gibi tanımlanmıştır: 
- TP: Gerçekte yeryüzünde ek oda olan nesnelerin görüntüde de 'ek oda' etiketiyle tespit edilerek doğru onaylanmasıdır.

- TN: Gerçekte yeryüzünde ek oda olmayan nesnelerin görüntüde de 'ek oda değil' etiketiyle tespit edilerek doğru reddedilmesidir.

- FP: Gerçekte yeryüzünde ek oda olmayan nesnelerin görüntüde 'ek oda' etiketiyle tespit edilerek hatalı onaylanmasidir.

- FN: Gerçekte yeryüzünde ek oda olan nesnelerin görüntüde 'ek oda değil' etiketiyle tespit edilerek hatalı reddedilmesidir.

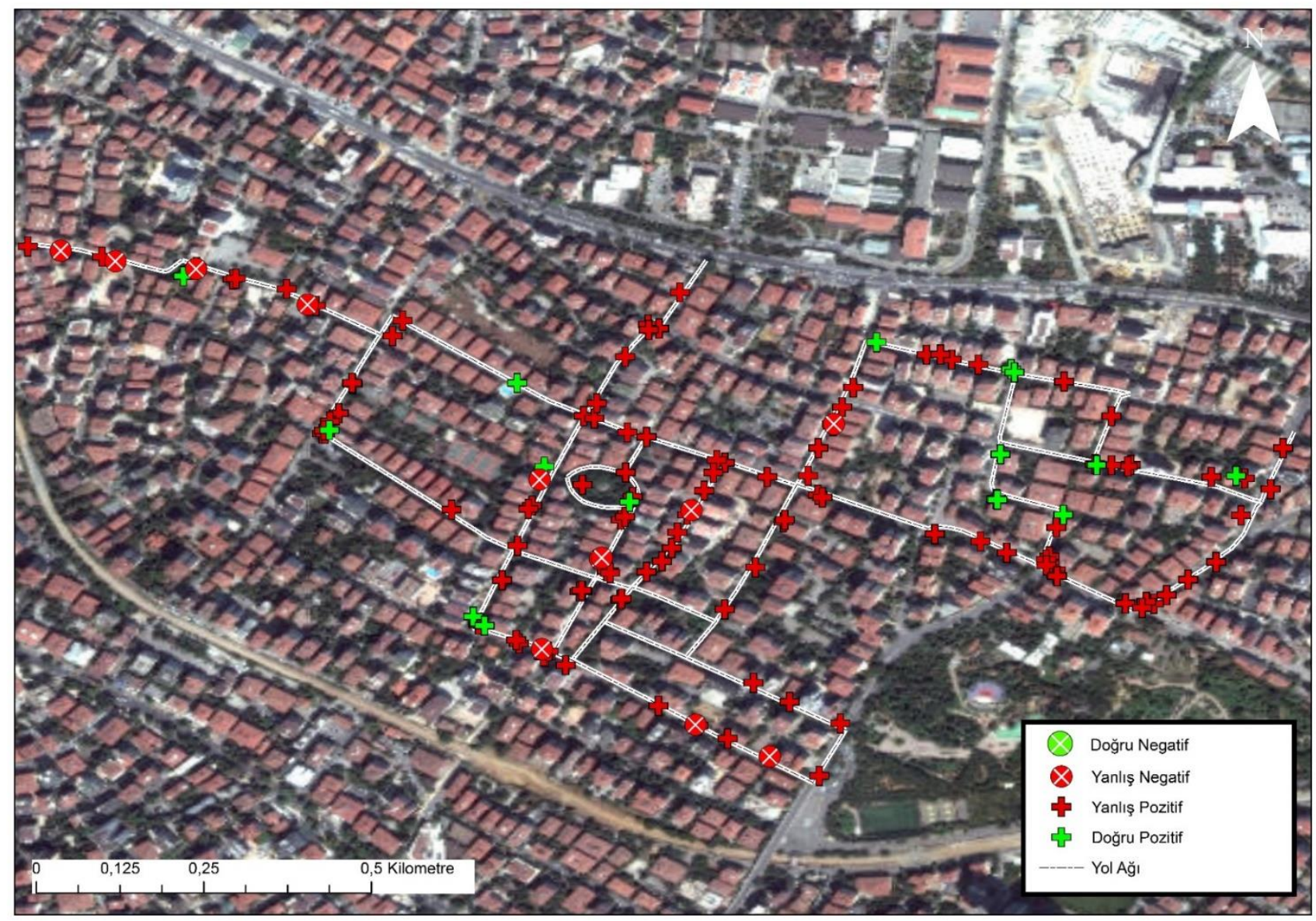

Şekil 9: Feneryolu Mahallesi çalışma bölgesindeki metriklerin dağıımı

Şekil 12'de çalışma kapsamında karşılaşılan ilginç FP örnekleri gösterilmektedir. Şekil 12 (a)'da görülen yol üzerindeki asfalt yaması ve Şekil 12 (b)'de görülen ağaç gölgesi derin öğrenme modeli tarafından ek odası olarak tahmin edilmiş̧ir. Şekil 12 (c)'de derin öğrenme modeli yağmur suyu kapağını, ek odası kapağı olarak etiketlemiştir.

Tablo 2: Üç çalışma bölgesine ait çapraşıklık matrisleri

\begin{tabular}{|c|c|c|c|c|c|c|c|}
\hline & & \multirow{2}{*}{\multicolumn{2}{|c|}{$\begin{array}{c}\text { Feneryolu } \\
\text { Gercek Deŏerler }\end{array}$}} & \multirow{2}{*}{\multicolumn{2}{|c|}{$\begin{array}{c}\text { Küçükbakkalköy } \\
\text { Gerçek Değerler }\end{array}$}} & \multirow{2}{*}{\multicolumn{2}{|c|}{$\begin{array}{c}\text { Yeni Mahalle } \\
\text { Gerçek Değerler }\end{array}$}} \\
\hline & & & & & & & \\
\hline & & Pozitif & Negatif & Pozitif & Negatif & Pozitif & Negatif \\
\hline \multirow{2}{*}{$\begin{array}{c}\text { Tahmin Edilen } \\
\text { Değerler }\end{array}$} & Pozitif & $\mathrm{TP}=16$ & $\mathrm{FP}=113$ & $\mathrm{TP}=24$ & $\mathrm{FP}=17$ & $\mathrm{TP}=16$ & $\mathrm{FP}=26$ \\
\hline & Negatif & $\mathrm{FN}=12$ & $\mathrm{TN}=0$ & $\mathrm{FN}=0$ & $\mathrm{TN}=0$ & $\mathrm{FN}=5$ & $\mathrm{TN}=0$ \\
\hline
\end{tabular}


Tablo 2'deki değerler üç çalışma bölgesi için ayrı ayrı aşağıdaki biçimde açıklanmıştır:

- Feneryolu Mahallesi için Mapillary platformunda kullanılan derin öğrenme modeli araç kamerasıyla kaydedilen sokak düzeyi görüntülerinden 141 noktayı ek odası olarak tahmin etmiştir. Belirlenen 141 noktanın 16 tanesi TP, 113 tanesi FP ve 12 tanesi de FN olarak etiketlenmiştir. Aynı bölgede akılı telefon kamerasıyla elde edilen görüntülerden ek oda tespit edilememiştir.

- Küçükbakkalköy Mahallesi için derin öğrenme modeli akıllı telefon kamerasıyla kaydedilen sokak düzeyi görüntülerden 41 noktayı ek odası olarak tahmin etmiştir. Belirlenen 41 noktanın 24 tanesi TP, 17 tanesi de FP olarak etiketlenmiştir. Aynı bölgede Mapillary platformunda kullanılan yapay öğrenme modeli araç kamerasıyla elde edilen görüntülerden 8 noktayı ek oda olarak tahmin etmiş olmasına rağmen, bu noktaların tümü gerçekte ek oda olmayıp FP olarak etiketlenmiştir.

- Yeni Mahalle için Mapillary platformunda kullanılan derin öğrenme modeli araç kamerasıyla kaydedilen sokak düzeyi görüntülerinden 47 noktayı ek odası olarak tahmin etmiştir. Belirlenen 47 noktanın 16 tanesi TP, 26 tanesi FP ve 5 tanesi de FN olarak etiketlenmiştir.

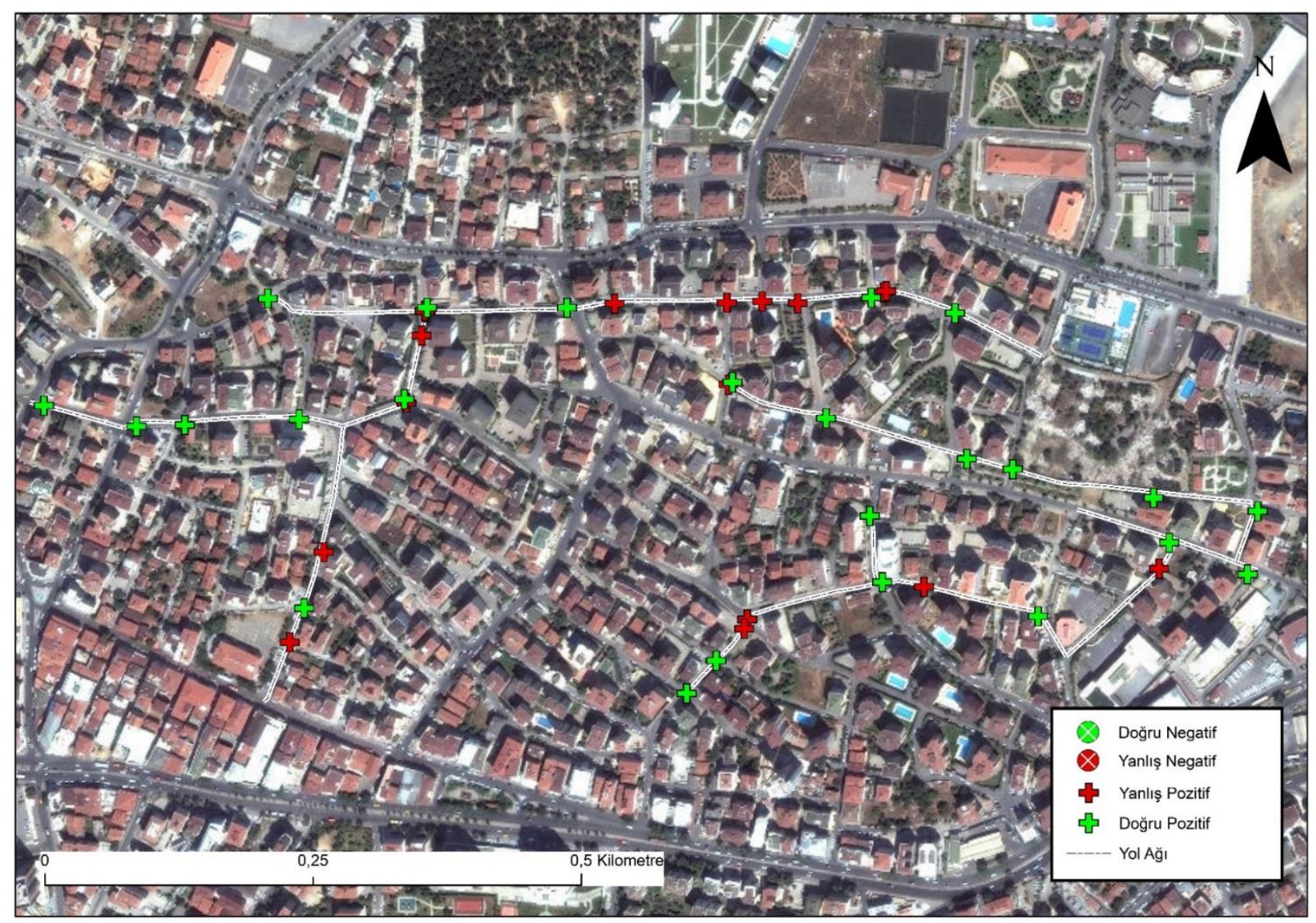

Şekil 10: Küçükbakkalköy Mahallesi çalışma bölgesindeki metriklerin dağıımı 


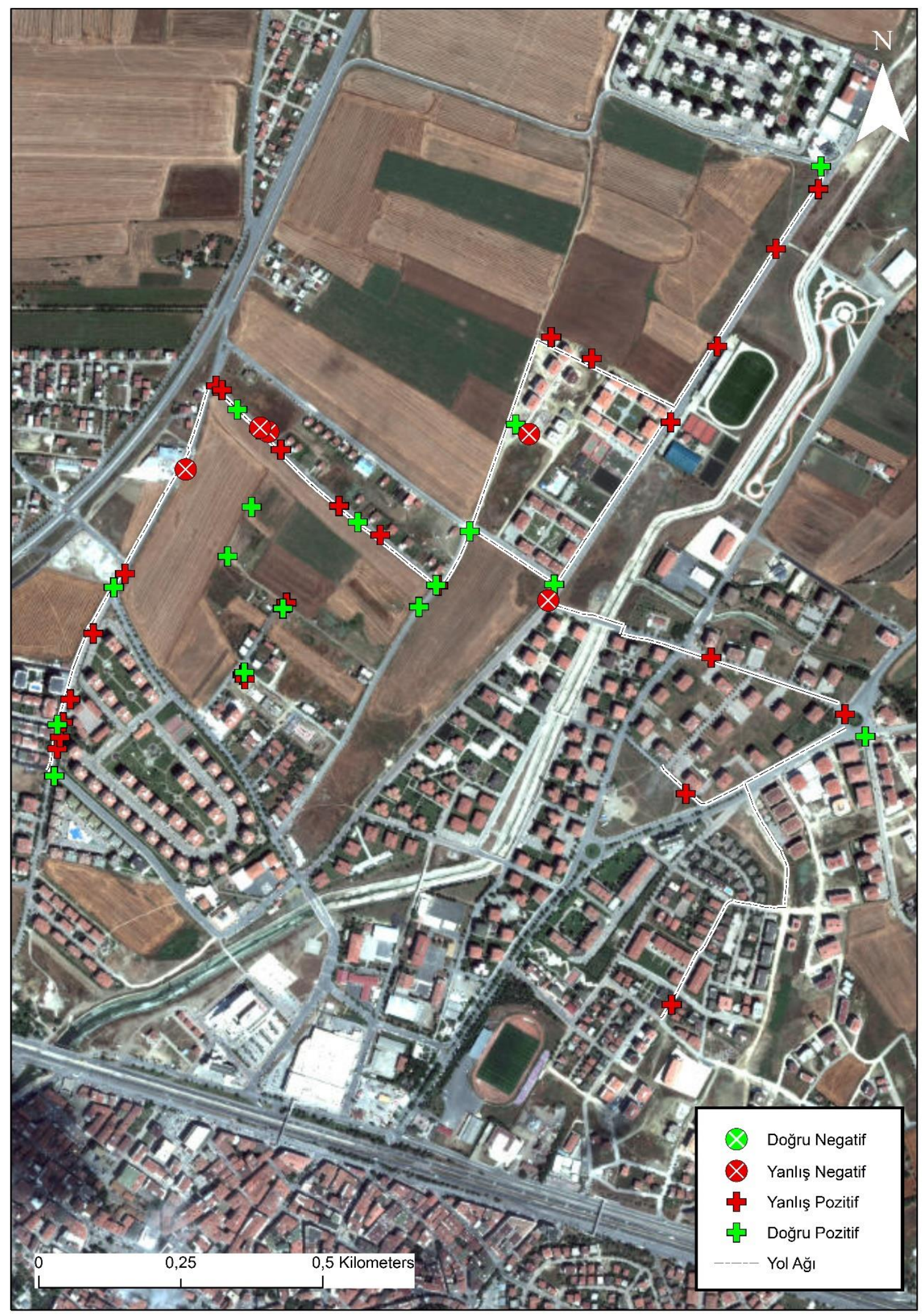

Şekil 11: Yeni Mahalle çalışma bölgesindeki metriklerin dağıımı

Feneryolu Mahallesi örneklemesi için derin öğrenme algoritmasının başarımı genel olarak değerlendirildiğinde bu çalışma bölgesi için FP olarak etiketlenen yani gerçekte ek oda olmayan ancak model tarafindan ek oda olarak kabul edilen örneklerin sayısının, gerçekten ek oda olup ek oda olarak etiketlenen örnek sayısının yaklaşık 7 katı olduğu görülmektedir. Ayrıca aynı 
veri kümesinde yanlış negatif diğer bir ifadeyle gerçekte ek oda olan ancak model tarafından ek oda olarak kabul edilmeyen örnekler de bulunmaktadır. Bu durumda yapay öğrenme modelinin Feneryolu Mahallesi veri kümesi için tahmin başarımının oldukça düşük kaldığı söylenebilir.

a)

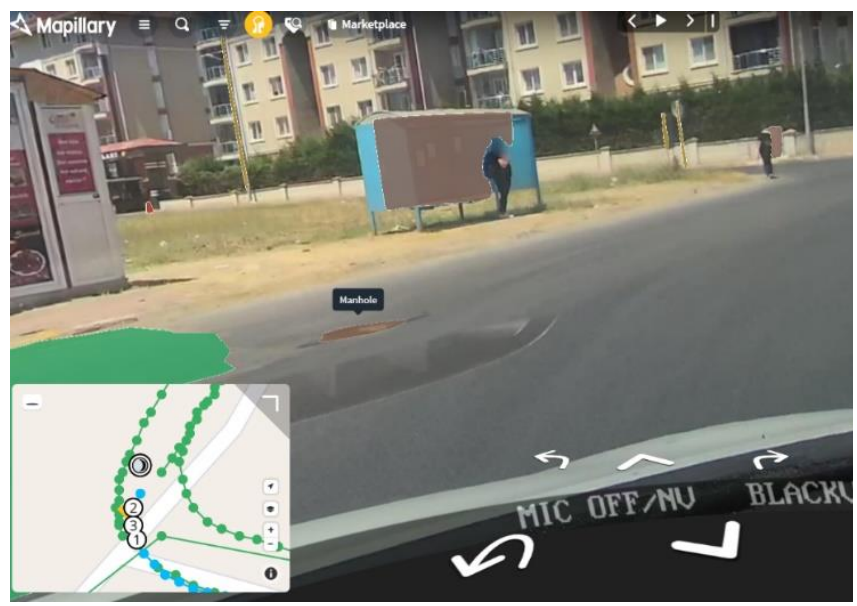

b)

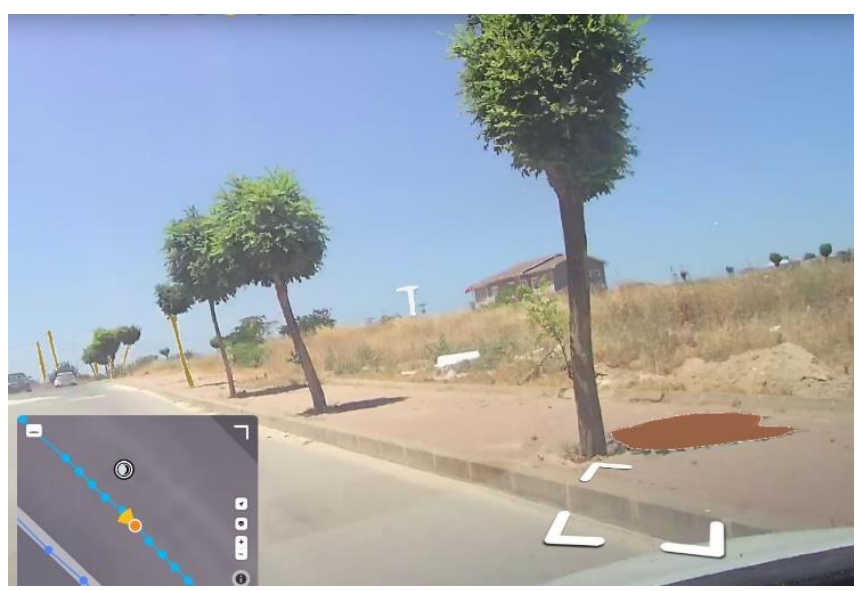

c)
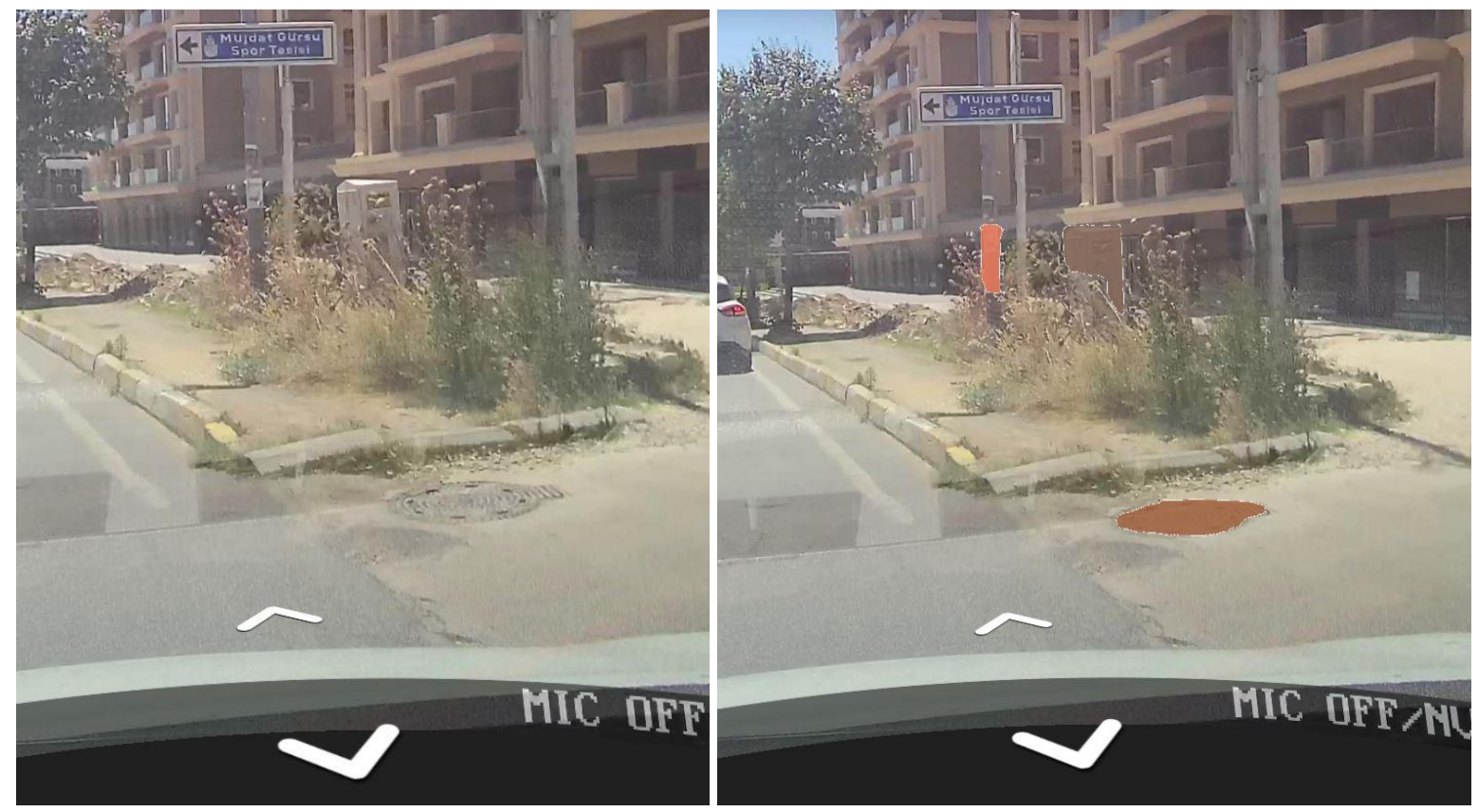

Şekil 12: FP örnekleri

Benzer değerlendirmenin Küçükbakkalköy Mahallesi'nden akıllı telefon ile elde edilen görüntüler üzerinden yapılması durumunda TP sayısının FP sayısından fazla olduğu görülmektedir. Derin öğrenme modelinin başarımı Küçükbakkalköy Mahallesi’nde elde edilen görüntüler için Feneryolu Mahellesi sonuçlarına göre görece daha yüksektir. Bununla birlikte, Küçükbakkalköy veri kümesi sonuçlarının akıllı telefon kamerasıyla elde edildiği, Feneryolu veri kümesi sonuçlarının ise araç kamerasıyla kaydedilen görüntülerden elde edilen sonuçlar olduğu unutulmamalıdır. Bu nedenle her iki veri kümesini birbirleriyle karşılaştırmak anlamlı olmayacaktır. Her ne kadar aynı derin öğrenme algoritması kullanılmış olsa da farklı görüntüleme donanımlarının ve tekniğinin kullanılmış olması girdi veri kümesine etki edeceğinden, her örnekleme bölgesinin kendi içinde değerlendirilmesi daha anlamlı bir yaklaşım olacaktır.

Küçükbakkalköy bölgesinde araç kamerası görüntülerine dayalı olarak model tarafından tahmin edilmiş olan 8 ek odası kapağı gerçekte ek odası kapağı olmayıp FP olarak etiketlenmiştir. Bu nedenle çalışma kapsamında Küçükbakkalköy 
Mahallesi'nde araç kamerasıyla elde edilen görüntüler değerlendirmeye alınamamıştır.

Yeni Mahalle’ye ilişkin veri kümesi araç kamerasıyla elde edilen görüntülerden oluşmaktadır. Feneryolu örneklemesinde olduğu gibi Yeni Mahalle örneklemesinde de FP sayısı TP sayısından daha fazladır. Ancak bu kez aradaki oran daha azdır. Benzer olarak veri kümesi içerisinde FN örnekler bulunmaktadır. Bu durumda Yeni Mahalle veri kümesi için de derin öğrenme algoritmasının sınıflandırma başarımı düşük kalmıştır. Bunula birlikte Feneryolu ve Yeni Mahalle veri kümeleri çapraşıklık matrisinde bulunan metrikler üzerinden karşılaştırıldığında Yeni Mahalle örneklemesinin daha başarılı sonuç verdiği ifade edilebilir.

Tablo 2'deki metriklere bakıldığında araç kamerası ile elde edilen görüntülerde ek odası kapakları, derin öğrenme modeli tarafından başarılı biçimde tahmin edilip sınıflandırılamamıştır. Diğer taraftan akıllı telefon kamerasıyla elde edilen görüntülerin başarımı araç kamerası ile elde edilen veri kümesine göre daha yüksek çıkmaktadır. Bunun nedeni akıllı telefon kamerasıyla elde edilen görüntülerin daha yakın mesafeden kayıt edilmiş olmaları olabilir. Araç kamerasıyla elde edilen görüntülerde başarımın düşük çıkmasının bir nedeni de yol güzergahında ilerleyen araç kamerası yol üstünde farklı birçok rögar, ızgara vb. kapakları kayıt etmektedir. Bu kapakların ayrı ayrı sınıflandırılmasında model başarılı olamamaktadır.

Çalışma kapsamında, görüntüler üzerinden ek odası kapağı tanımlama başarımının daha iyi analiz edilebilmesi için çapraşıklık matrisinde yer alan metrikleri kullanan doğruluk, hassasiyet, duyarlılık gibi başkaca ölçütlerden yararlanılmıştır.

Doğruluk yapay öğrenme modelinin sınıflandırıcısının ne kadar başarılı çalıştığını veya ne sıklıkta doğru tahmin gerçekleştirdiğini gösterirken, tahmin hatası (prediction error) da tersine tahminlerdeki hata miktarını göstermektedir. Bu nedenle her ikisinin toplamları bire eşit olmalıdır (Fawcett, 2006; Tharwat, 2018).

Hassasiyet tahmin edilen pozitif sınıflarda gerçekte ne kadar doğru tahmin gerçekleştirildiği bilgisini verirken, duyarlılık ise gerçek pozitif sınıflarda ne kadar doğru tahmin yapıldığını göstermektedir. F1-ölçüsü (F1-score), aritmetik ortalama yerine harmonik ortalamayı kullanarak hassasiyet ve duyarlılı̆̆ın aynı anda değerlendirilmesini sağlamaktadır (Fawcett, 2006; Tharwat, 2018).

Özgüllük (specificity) metriği gerçek negatif sınıflara ait olan doğru negatiflerin ne doğrulukta bulunabildiğini göstermektedir (Fawcett, 2006; Tharwat, 2018).

Alıcı İşletim Karakteristik Eğrisi (Receiver Operating Characteristic Curve, ROC Curve); TP oranı (TP Rate, TPR) ve FP oranını (FP Rate, FPR) metriklerinin X ve Y eksenlerine yerleştirildiğinde eğrinin altında kalan alanın hesaplanması ile elde edilmektedir. Eğrinin altında kalan alan ne kadar büyükse yapay öğrenme modelinin başarı oranı da o kadar yüksek demektir (Powers, 2011).

Sözü edilen ölçütlerin nasıl hesaplandığı aşağıdaki eşitliklerde gösterilmiştir (Tharwat, 2018):

$$
\begin{aligned}
& \text { Doğruluk }=\frac{T P+T N}{T P+F P+T N+F N} \\
& \text { Hassasiyet }=\frac{T P}{T P+F P} \\
& \text { Duyarlılık }=\frac{T P}{T P+F N}
\end{aligned}
$$


$F 1-$ ölçüsü $=\frac{2 \times \text { Hassasiyet } \times \text { Duyarlılık }}{\text { Hassasiyet }+ \text { Duyarlılık }}$

Tahmin Hatasl $=\frac{F P+F N}{T P+F P+T N+F N}$

Özgüllük $=\frac{T N}{F P+T N}$

Doğru Pozitif Oranı $=\frac{T P}{T P+F N}$

Yanlış Pozitif Oranı $=\frac{F P}{F P+F N}$

Tablo 2'de verilen matris üzerindeki metrikler kullanılarak her üç mahallenin veri kümelerine ilişkin yapay öğrenme algoritmasının sınıflandırıcısının başarım ölçütleri Tablo 3’te verilmiştir.

Tablo 3: Yapay öğrenme modelinin tanımlama başarısı için kullanılan ölçütler

\begin{tabular}{cccccccc} 
& \multicolumn{3}{c}{ Çalışma Bölgesi } \\
\cline { 2 - 8 } Ölçütler & \multicolumn{2}{c}{ Feneryolu } & \multicolumn{2}{c}{ Küçükbakkalköy } & \multicolumn{2}{c}{ Yeni Mahalle } \\
\hline Doğruluk & 0.11 & $\% 11$ & 0.59 & $\% 59$ & 0.34 & $\% 34$ \\
\hline Tahmin Hatas1 & 0.89 & $\% 89$ & 0.41 & $\% 41$ & 0.66 & $\% 66$ \\
\hline Hassasiyet & 0.12 & $\% 12$ & 0.59 & $\% 59$ & 0.38 & $\% 38$ \\
\hline Duyarlıl1k & 0.57 & $\% 57$ & 1.00 & $\% 100$ & 0.76 & $\% 76$ \\
\hline F1-ölçüsü & 0.20 & $\% 20$ & 0.74 & $\% 74$ & 0.51 & $\% 51$ \\
\hline Özgüllük & 0.00 & $\% 0$ & 0.00 & $\% 0$ & 0.00 & $\% 0$ \\
\hline TPR & 0.57 & $\% 57$ & 1.00 & $\% 100$ & 0.76 & $\% 76$ \\
\hline FPR & 1.00 & $\% 100$ & 1.00 & $\% 100$ & 1.00 & $\% 100$ \\
\hline
\end{tabular}

Tablo 3 incelendiğinde çalışma bölgeleri arasında başarımı en yüksek olan veri kümesinin Küçükbakkalköy örneklemesi olduğu görülmektedir. Bunun temel nedeni Küçükbakkalköy çalışma bölgesinde akıllı telefon kamerasının kullanılmış olmasidir.

Küçükbakkalköy Mahallesi’nde elde edilen görüntülerin Mapillary platformunda kullanılan derin öğrenme modelinde sınıflandırılması sonucunda model doğruluğu \%59 düzeyinde olup üç mahalle arasında doğruluğu en yüksek çalışma bölgesidir. Bir diğer ifadeyle sınıflandırıcı görüntülerde bulunan 100 nesnenin yalnızca 59 tanesini doğru sınıflandırabilmiştir. Her ne kadar üç çalışma bölgesi arasında en yüksek doğruluk değeri olsa da gerçek uygulamalarda kullanmak için yeterli doğrulukta değildir. En yüksek hassasiyet değeri de Küçükbakkalköy veri kümesi için hesaplanmış ve doğruluk ölçütü ile aynı değer elde edilmiştir. Başka bir ifadeyle model, ek odası kapağı olarak tahmin ettiği nesnelerin yalnızca \%59’u gerçekten ek odası kapağıdır. Küçükbakkalköy veri kümesinde sahte negatif bulunmadığı için duyarlılık metriği otomatik olarak 1 çıkmaktadır.

Tablo 3'teki başarım ölçütleri karşılaştırıldığında araç kamerasıyla görüntü elde edilen iki çalışma bölgesi arasında daha yüksek başarım sağlanan bölge Yeni Mahalle olmuştur. Yeni Mahalle veri kümesi için doğruluk \%34, hassasiyet \%38 ve duyarlılık \% 76 olarak hesaplanmıştır. Diğger bir ifadeyle, görüntülerde bulunan 100 nesneden 34 tanesi doğru tespit edilmiştir. Görüntüler üzerinde ek odası olarak tahmin edilen nesnelerin \%38'i TP yani gerçekten ek odasıdır. Derin öğrenme modeli gerçekte ek odası olan nesnelerin ancak \%76’sını TP olarak tespit edebilmektedir.

Çalışma kapsamındaki veri kümeleri içerisinde TN etiketlenmesi örneği hiç bulunmadığından FPR ölçütleri 1 olarak hesaplanmıştır. Bu nedenle ROC eğrileri anlamlı olmamaktadır. Özgüllük ölçütü görüntülerde ek odası olmadığı durumda 
yani TN sınıflarda ek odası tespit edilme olasılı̆ı̆ını göstermektedir. Ancak çalışma kapsamındaki örneklemelerde TN etiketlemesi olmadığı için özgüllük değerleri 0 çıkmaktadır.

Yenilikçi yöntemle ek odası kapaklarının tanıma başarımının iyileştirilebilmesi için öncelikle modelin kullandığı eğitim veri kümesindeki doğrulama çalışmalarının sayısal olarak arttırılması gerekmektedir. Bölüm 3.2'de ifade edilen ve Şekil 7'de gösterilen gönüllü kullanıcıların gerçekleştirdiği doğrulama çalışmaları kapsamında, gönüllüler tarafından incelenen görüntü sayısının toplam görüntü sayısına oranı yaklaşık \%3.7 düzeyindedir. Bir gözetimli öğrenme (supervised learning) süreci için bu oranın yükseltilmesi, en azından \%10 düzeyine çıkarılması gerekmektedir.

Bu savı destekleyecek olan konulardan biri de dünyada ve Türkiye'de farklı telekomünikasyon firmalarının Şekil 13'te görüldüğü üzere farklı şekil, renk ve büyüklükte ek odası kapakları kullanmalarıdır. Başka bir ifadeyle ek odası kapağı için şekil, büyüklük ve renk açısından belirlenmiş bir standart bulunmamakta ve bu durumda ek odası kapağının sokak düzeyi görüntüler üzerinden tanımlanma başarımını etkilemektedir. Genelde daire veya dikdörtgen şeklinde olan ek odası kapakları geçmişte demir döküm malzemeden üretilmekteyken bugün daha ekonomik ve hafif olan kompozit malzeme kullanılmaktadır. Çalışma kapsamında yapay öğrenme algoritması sınıflandırıcısının Şekil 12 (c)'de gösterilen yağmur suyu kapakları Şekil 13’te gösterilen ek odası kapaklarını ayırmadaki düşük başarımı FP örneklemelerin artmasına neden olmuştur.

\subsubsection{Görüntülerden Tespit Edilen Ek Odası Kapaklarının Konum Kestirimi Açısından Değerlendirilmesi}

Üç ayrı çalışma alanında bulunan tüm ek odası kapaklarının iki boyutlu koordinat değerleri Uluslararası Yersel Referans Sistemi (International Terrestrial Reference Frame 2005 (ITRF05) datumunda 2005.0 epoğunda $30^{\circ}$ dilim orta meridyeni $3^{\circ}$ dilim genişlikli Gauss-Krüger projeksiyonunda sağa ve yukarı koordinat çifti olarak hesaplanmıştır. GNSS uydu tekniğiyle ölçülen ek odaların 2B koordinat değerleri daha güvenilir ve yüksek doğrulukta olduğundan referans veri kümesi (ground truth data set) olarak kabul edilmiştir. Sokak düzeyi görüntülerinden tespit edilmiş olan ek odası kapaklarının World Geodetic System (WGS-84) datumunda ve ölçü epoğundaki koordinat değerleri doğruluk analizinde test noktası olarak alınmıştır.

Feneryolu Mahallesi'nde yapılan çalışmalarda Tablo 1'de görüleceği üzere 58 tane ek odası kapağının konumları GNSS gözlemleri ile belirlenmiştir. Tablo 2'de görüleceği üzere Feneryolu Mahallesi'nde sokak düzeyi görüntülerinden Mapillary platformu derin öğrenme yaklaşımı ile 16 adet TP ek odası tespit etmiştir. Küçükbakkalköy Mahallesi'nde yapılan çalışmalarda 45 tane ek odasının koordinatları GNSS gözlemleri ile belirlenmiştir. Küçükbakkalköy Mahallesi’nde sokak düzeyi görüntülerinden 24 adet TP ek odası tespit etmiştir. Yeni Mahalle'de GNSS tekniği kullanılarak koordinatları belirlenen ek odası sayısı 75'tir. Yeni Mahalle'de görüntüler üzerinden tespit edilen TP sayısı da 16'dır. Farklı yöntemlerle üretilen her iki veri kümesinde eşleşen ortak noktalar TP noktalardır. Bu durumda Feneryolu Mahallesi’nde 16, Küçükbakkalköy Mahallesi’nde 25 ve Yeni Mahalle'de 16 nokta üzerinden yenilikçi yöntemle elde edilen koordinat değerlerinin, geleneksel yöntemle üretilmiş referans koordinat değerlerinden olan farklılıkları ve standart sapmaları hesaplanmıştır. Sağa ve yukarı koordinat bileşenlerinde ayrı ayrı koordinat farkları grafik üzerinden incelendiğinde farkların normal dağılımda olduğu görülmüştür. Tablo 4'te üç çalışma bölgesi için ayrı ayrı referans ve test noktalarının koordinat farklarına ilişkin en küçük ve en büyük koordinat farkları ile standart sapma gibi kalite bilgileri verilmiştir.

Tablo 4 incelendiğinde Feneryolu Mahallesi’nde GNSS tekniğiyle elde edilen koordinat değerleri ile yenilikçi yöntemle elde edilen koordinat değerleri farklarının ortalama $1.5 \mathrm{~m}$ dolayında olduğu görülmesine karşın en büyük farkların 20 m'yi geçtĭgi görülmektedir. Bu durum standart sapma değerlerine de yansımış ve standart sapma yaklaşık $10 \mathrm{~m}$ olarak hesaplanmıştır. Feneryolu Mahallesi gibi yoğun yerleşimin, yüksek yapılaşmanın, dar sokakların olduğu yerlerde koordinat farklarının ve dolayısıyla konum belirleme hatalarının yüksek olduğu, Yeni Mahalle gibi daha kırsal alanda bulunan yerlerde farkların ve 
hataların görece daha düşük olduğu görülmektedir.

Tablo 4: Üç çalışma bölgesine ait koordinat farklarının kalite bilgileri

\begin{tabular}{|c|c|c|c|c|c|c|}
\hline \multirow[b]{3}{*}{ Koordinat Bileşeni } & \multicolumn{6}{|c|}{ Çalışma Bölgesi } \\
\hline & \multicolumn{2}{|c|}{ Feneryolu } & \multicolumn{2}{|c|}{ Küçükbakkalköy } & \multicolumn{2}{|c|}{ Yeni Mahalle } \\
\hline & $\Delta$ Sağa (m) & $\Delta$ Yukarı (m) & $\Delta$ Sağa (m) & $\Delta$ Yukarı (m) & $\Delta$ Sağa (m) & $\Delta$ Yukarı (m) \\
\hline Ortalama $(\mu)$ & -1.38 & -1.61 & -0.42 & 1.16 & 0.30 & 0.09 \\
\hline Pozitif En Büyük Fark & 16.92 & 11.68 & 3.97 & 9.20 & 7.26 & 5.24 \\
\hline Negatif En Büyük Fark & -23.90 & -28.03 & -4.94 & -3.86 & -3.55 & -3.78 \\
\hline Standart Sapma $(\sigma)$ & 9.55 & 10.78 & 2.70 & 3.27 & 2.65 & 2.81 \\
\hline Standart Hata $\left(m_{\sigma}\right)$ & 2.39 & 2.69 & 0.55 & 0.67 & 0.66 & 0.70 \\
\hline
\end{tabular}

Sokak düzeyi görüntülerinin elde edildiği kameraların bütünleşik olarak çalıştığı tek frekanslı gömülü GNSS çipleri mutlak konum belirleme yöntemini kullanmaktadır. Literatürde bu yöntemin konum belirleme doğruluğu yaklaşık $\pm 10 \mathrm{~m}$ dolayındadır. Diğer taraftan geleneksel yöntemde jeodezik ölçme amaçlı geliştirilen çift frekanslı bir GNSS alıcısı bağıl konum belirleme yöntemiyle gerçek zamanlı kinematik konum belirleme tekniğini kullanarak dm altı doğrulukta konum bilgisi üretmektedir. Her ne kadar Mapillary platformu GNSS tabanlı konum bilgilerini SfM algoritması ile birlikte kullanarak ek odası kapaklarının konum bilgilerini üretiyor olsa da, yenilikçi yöntemle üretilen konum bilgisi kalitesi geleneksel yönteme göre çok düşük düzeyde kalmaktadır.

Buradan hareketle çalışma kapsamındaki yenilikçi yöntemin yaklaşık olarak metre altı doğruluk gerektiren şebeke bilgi sistemlerinin oluşturulması için gerekli konum doğruluğunu sağlayamadığı görülmüştür.

Yenilikçi yöntemin konum belirleme kalitesinin iyileştirilebilmesi için kameraların görüntü elde etme anındaki konumları aşağıdaki yaklaşımlarla desteklenebilir:

- Kamera konumunu belirlemek için hem araçtaki kamerayla bütünleşik çalışan hem de akıllı telefonda gömülü olarak bulunan GNSS kartları, L1 ve L2 gibi çift frekansta GPS sinyali alabilen özellikte seçilebilir. Ayrıca hem araç tarafında hem de akıllı telefonda yalnız gerçek zamanlı konum bilgisi üreten özellikte GNSS çipleri değil aynı zamanda ham veri kaydı yapabilen ve dolayısıyla daha sonra GNSS gözlemlerinin değerlendirilebilmesine olanak veren türde GNSS donanımları tercih edilebilir.

- Kamera konumunu belirlemek için mutlak konum belirleme tekniklerinden olan Hassas Nokta Konum Belirleme (Precise Point Positioning, PPP) tekniği kullanılarak konum kalitesi iyileştirilebilir. Bu tür bir tekniğin kullanılması, mevcutta kullanılan mutlak konum belirleme tekniğinden farklı olarak hassas uydu yörünge ve saat bilgilerinin konum belirleme sürecine dahil edilmesiyle daha yüksek doğrulukta konum bilgisinin üretilmesini sağlayacaktır. Bunun için de öncelikle araçta ve akıllı telefon tarafından çift frekanslı GPS sinyali alabilen bir alıcıya gereksinim bulunmaktadır.

- Kamera konumunun belirlenmesinde bağıl konum belirleme yöntemi geleneksel yöntemdekine benzer biçimde gerçek zamanlı kinematik konum belirleme tekniği yaklaşımıyla kullanılabilir. Örneğin İstanbul'da İSKİ UKBS gibi sürekli hizmet veren ağlardan destek alınarak kamera konum bilgisi daha yüksek doğrulukta üretilebilir. Yine burada da çift frekanslı bir alıcının kullanılması durumunda konum doğruluğu desimetre altında elde edilebilirken, tek frekanslı bir alıcı ile DGPS tekniğinin kullanılması durumunda ise metre altında bir doğruluk elde edilebilecektir. 


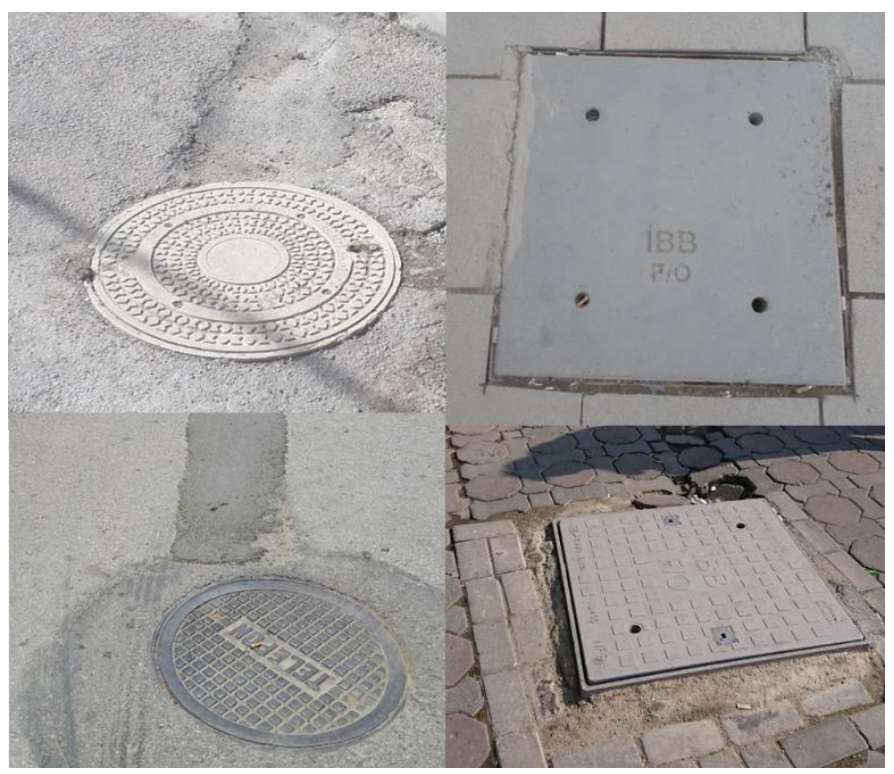

Şekil 13: Türkiye'de kullanılan ek odası kapak örnekleri

Ayrıca yenilikçi yöntemin başarımını arttırmada konum bilgi üretiminin doğruluğunun arttırılmasına ek olarak, sokak düzeyi görüntülerinin sayısının arttırılması, dolayısıyla görüntülerden üretilecek nokta bulutunun yoğunluğunun artması olumlu katkı yapacaktır.

\subsubsection{Diğer Açılardan Değerlendirme}

Tablo 5 incelendiğinde çalışma kapsamındaki üç çalışma bölgesi için yenilikçi yöntemle harita bilgisi üretme işinin maliyet, zaman ve emek açısından geleneksel yöntemle karşılaştırıldığında çok daha üstün durumda bulunduğu görülmektedir. Yalnız bu açılardan değerlendirildiğinde yenilikçi yöntem, telekomünikasyon sektörünün beklentilerini geleneksel yönteme göre daha çok sağlamaktadır. Bu durumda yenilikçi yöntemin doğruluk açısından başarımının yükselmesi durumunda geleneksel yöntemin yerini hızlıca alacağını göstermektedir.

Tablo 5: Geleneksel ve yenilikçi yöntemlerin maliyet bilgileri

\begin{tabular}{|c|c|c|c|c|c|c|c|}
\hline Çalışma Bölgesi & $\begin{array}{c}\text { GNSS Gözlem } \\
\text { Tarihi }\end{array}$ & \multicolumn{2}{|c|}{$\begin{array}{c}\text { GNSS Tekniği ile } \\
\text { Ölçülen Ek } \\
\text { Odası Sayısı }\end{array}$} & $\begin{array}{c}\text { GNSS Gözlem } \\
\text { Süresi }\end{array}$ & \multicolumn{2}{|c|}{$\begin{array}{l}\text { Arazideki Ölçme } \\
\text { Operatörü Sayısı }\end{array}$} & Ölçme Maliyeti \\
\hline Feneryolu & Ağustos 2019 & 58 & & 3 gün (25 saat) & & 2 & $5000.00 \mathrm{TL}$ \\
\hline Küçükbakkalköy & A ğustos 2019 & 45 & & 2 gün (15 saat) & & 1 & $4000.00 \mathrm{TL}$ \\
\hline Yeni Mahalle & May1s 2020 & 75 & & 4 gün (30 saat) & & 1 & $7000.00 \mathrm{TL}$ \\
\hline Toplam & & 178 & & 9 gün (70 saat) & & & $16000.00 \mathrm{TL}$ \\
\hline Çalış & $\begin{array}{c}\text { Görüntülerin } \\
\text { Elde Edildiği } \\
\text { Tarih } \\
\end{array}$ & $\begin{array}{c}\text { Görüntülerden } \\
\text { Elde Edilen Ek } \\
\text { Odası Sayısı } \\
\end{array}$ & Göri & $\begin{array}{l}\text { intü Kayıt } \\
\text { Süresi }\end{array}$ & $\begin{array}{l}\text { eratör } \\
\text { ayısı }\end{array}$ & $\begin{array}{c}\text { Ölçme } \\
\text { Maliyeti }\end{array}$ & $\begin{array}{c}\text { Araç } \\
\text { Güzergahının } \\
\text { Uzunluğu } \\
\end{array}$ \\
\hline Feneryolu & Ağustos 2019 & Araçla 16/141 & & $\begin{array}{l}\text { çla } 1 \text { gün } \\
.5 \text { saat) }\end{array}$ & 1 & $300.00 \mathrm{TL}$ & $4 \mathrm{~km}$ \\
\hline Küçükbakkalköy & Ağustos 2019 & $\begin{array}{c}\text { Araçla 0/8 } \\
\text { Telefonla 24/41 }\end{array}$ & $\begin{array}{r}\text { Araç } \\
\text { saat) } \\
1 \mathrm{gi}\end{array}$ & $\begin{array}{l}\text { la } 1 \text { gün (1 } \\
\text { Telefonla } \\
\text { in ( } 3 \text { saat) }\end{array}$ & 1 & $300.00 \mathrm{TL}$ & $5 \mathrm{~km}$ \\
\hline Yeni Mahalle & Mayıs 2020 & Araçla 16/47 & Araç & $\begin{array}{l}\text { la } 1 \text { gün (1 } \\
\text { saat) }\end{array}$ & 1 & $200.00 \mathrm{TL}$ & $6 \mathrm{~km}$ \\
\hline Toplam & & $56 / 237$ & 3 güı & n (6.5 saat) & 1 & $800.00 \mathrm{TL}$ & $15 \mathrm{~km}$ \\
\hline
\end{tabular}

Sokak düzeyi görüntülerinin elde edilmesinde bu çalışma kapsamındaki yenilikçi yöntemden farklı olarak Gezgin Harita Sistemleri (Mobile Mapping Systems, MMS) de kullanılmaktadır. Gezgin harita sistemleri de bu çalışmada kullanılan 
tekniklere benzer biçimde hem birçok farklı tür alıcıyı barındıran hareketli platformlar hem de sırt çantası özelinde tasarlanan ve operatörün yürürken ortamı ölçen sistemler olarak kullanılabilmektedir. Bu tür sistemler kullanılarak geliştirilmiş çözümlere örnek olarak Google Street View gösterilebilir.

Çalışma kapsamında kullanılan yenilikçi yöntemle, profesyonel bir çözüm olarak geliştirilen gezgin harita üretim sistemleri arasında maliyet açısından büyük farklar bulunmaktadır. Gezgin harita üretim sistemleri yüksek doğruluklu GNSS alıcıları, çoklu kameralı optik görüntüleme sistemleri, çoklu tarayıcılı lazer tarama sistemleri, navigasyon sistemleri gibi üst düzey ve yüksek maliyetli donanımlar kullanmakta ve farklı yapıdaki veri kümelerinin bütünleştirilmesi için de yüksek maliyetli veri değerlendirme süreçlerini gerektirmektedir. Ayrıca, yüksek veri üretim ve değerlendirme maliyetleri aynı bölgeye ait verinin elde edilme sıklığını da azaltmaktadır. Oysaki çalışmada yararlanılan yenilikçi yöntem son derece düşük maliyetli ve hızlı sonuç üreten bir çözüm olup istenilen sıklıkta gerçekleştirilmesi yüksek bir maliyet oluşturmamaktadır.

\subsubsection{Yenilikçi Yöntem Kapsamında Kullanılan İki Farklı Tekniğin Karşılaştırılması}

Üç çalışma bölgesinin hiçbirinde her iki tekniğin aynı anda anlamlı veri kümesi üretebildiği bir örnekleme oluşturulamadığından çalışma kapsamında yenilikçi yöntem kapsamında kullanılan iki farklı tekniğin başarımı karşılaştırılamamıştır. Çalışma kapsamında elde edilen deneyimlere dayanılarak Tablo 6' da ifade edilen değerlendirmeler ortaya çıkarılmıştır.

Tablo 6: Geleneksel ve yenilikçi yöntemlerin maliyet bilgileri

\begin{tabular}{|c|c|c|c|}
\hline \multicolumn{2}{|c|}{ Araç Üzerinden Görüntülerin Elde Edilmesi } & \multicolumn{2}{|c|}{$\begin{array}{l}\begin{array}{l}\text { Yürürken Akıllı Telefonla Görüntülerin Elde } \\
\text { Edilmesi }\end{array} \\
\end{array}$} \\
\hline Olumlu Yönleri & Olumsuz Yönleri & Olumlu Yönleri & Olumsuz Yönleri \\
\hline $\begin{array}{c}\text { Aracın hareketiyle } \\
\text { ilerlendiği için görüntü } \\
\text { elde etme hızının yüksek } \\
\text { olması }\end{array}$ & $\begin{array}{l}\text { Kaldırım üzerinde } \\
\text { bulunan ek odası } \\
\text { kapakları yol kenarına } \\
\text { park eden araçlar } \\
\text { nedeniyle } \\
\text { görüntülenememekte }\end{array}$ & $\begin{array}{c}\text { Araçla görüntü kaydına } \\
\text { göre araç park } \\
\text { sorunundan çok daha az } \\
\text { etkilenmesi }\end{array}$ & $\begin{array}{c}\text { İnsan hareketiyle } \\
\text { ilerlendiği için görüntü } \\
\text { elde etme hızının düşük } \\
\text { olması }\end{array}$ \\
\hline $\begin{array}{l}\text { Geniş aç1lı görüntü elde } \\
\text { edebilme }\end{array}$ & $\begin{array}{l}\text { Görüntü kaydı sırasında } \\
\text { araç camından yansıyan } \\
\text { nesneler hatalı tahmin } \\
\text { yapılmasına neden } \\
\text { olmakta }\end{array}$ & $\begin{array}{c}\text { Camdan yansıyan 1şıktan } \\
\text { etkilenmemesi }\end{array}$ & $\begin{array}{l}\text { Daha dar açılı görüntü } \\
\text { elde etme }\end{array}$ \\
\hline $\begin{array}{l}\text { Sensörler için güç } \\
\text { kaynağı kısıdının } \\
\text { olmaması }\end{array}$ & $\begin{array}{l}\text { Görüntüler yol üzerinden } \\
\text { elde edildiği için yapay } \\
\text { öğrenme modeli yol } \\
\text { üzerinde bulunan yağmur } \\
\text { suyu ve rögar kapaklarını } \\
\text { da ek odası olarak } \\
\text { etiketlemesi }\end{array}$ & $\begin{array}{l}\text { Operatörün kaldırım } \\
\text { üzerinde yürüyerek } \\
\text { görüntü elde etmesi } \\
\text { nedeniyle yol üzerinde } \\
\text { bulunan yağmur suyu ve } \\
\text { rögar kapaklarının } \\
\text { modelin tahmin } \\
\text { başarımını etkilememesi }\end{array}$ & $\begin{array}{l}\text { Kamera akıllı telefon } \\
\text { kapsamında olduğundan } \\
\text { güç kaynağ1 kısıdının } \\
\text { olması }\end{array}$ \\
\hline $\begin{array}{l}\text { Araç kullanımı dışında } \\
\text { görüntü elde edilmesi } \\
\text { tamamen otomatik } \\
\end{array}$ & & & \\
\hline
\end{tabular}

\section{Sonuçlar}

Çalışma kapsamında telekomünikasyon sektöründe kullanılan ek odaların yenilikçi yöntem olarak nitelendirilen çözümle tespit etme ve konumlarını belirleme başarımı, telekomünikasyon sektöründe halihazırda kullanılan geleneksel yöntemle farklı açılardan karşılaştırılmıştır. Diğer bir ifadeyle temel olarak GNSS gözlemlerinin kullanıldığı ek odası mekansal bilgi üretme süreci ile sokak düzeyi görüntülerden derin öğrenme yaklaşımı ile ek odasının ilgi noktası olarak harita bilgisi biçiminde üretilme süreci doğruluk, zaman, maliyet gibi farklı yönlerden karşılaştırılarak başarım analizi yapılmıştır. Genel 
olarak yenilikçi yöntemin, ek odası kapaklarını otomatik tanıma başarımının düşük düzeyde kaldığı görülmüş̧ür. Yenilikçi yöntemle tespit edilen ek odası kapaklarının belirlenen konum bilgilerinin de geleneksel yöntemle belirlenmiş olan konum bilgilerine göre oldukça farklı olduğu görülmüştür. Konum ve tanıma doğruluklarıyla ilgili başarım sonuçları göz önüne alındığında yenilikçi yöntemin geleneksel yöntemin tamamen yerini alması bu çalışma kapsamındaki sonuçlarla olası görülmemektedir. Ancak değerlendirmeye konu sokak düzeyi görüntülerinin kalitesinin artması, görüntüleri değerlendiren derin öğrenme modelinin gelişmesiyle zaten daha az kaynak, zaman ve iş gücü gerektiren yenilikçi yöntemin geleneksel yöntemin yerini alacağı açıktır. Benzer durum derin öğrenme ile yüz tanıma modellerinde yaşanmış, önceleri başarımı düşük olan yapay öğrenme modelleri bugün gelinen noktada yüz tanıma konusunda insanın yüz tanıma başarımını geçmiştir. Bu benzeşimden yola çıkarak yenilikçi yöntemin, geleneksel yöntemin başarımını yakalamasının uzun sürmeyeceği söylenebilir.

Çalışma kapsamında yenilikçi yöntemin başarımı yalnız bir platformdan yani Mapillary platformundan elde edilen sonuçlara göre değerlendirilmiştir. Çalışma sonucunun daha anlamlı olması için aynı veri kümesinin benzer işi yapan OpenStreetCam, GEODI 360 gibi diğer platformlarda da değerlendirilmesi gerekmektedir. Bu tür bir yaklaşım aynı zamanda önceden eğitilmiş yapay öğrenme modelleri kullanılarak geliştirilmiş platformların; varlık/nesne tanıma ve tanımlanan nesnelerin konum bilgilerini üretme çözümleri arasında, nesne tanıma başarımları ve konum doğrulukları açısından karşılaştırma yapılabilmesini sağlayacaktır.

Telekomünikasyon firmaları tarafından gerçekleştirilen bakım onarım faaliyetleri kapsamında ek odaların varlığını koruyup koruyamadığı bilgisine gereksinim duymaları nedeniyle koordinatları bilinen noktalarla karşılaştırmak için çalışma kapsamında önerilen yöntemin kullanılabileceği düşünülmektedir. CBS ortamında ve mekansal veri tabanında olmayıp yenilikçi yöntemle tespit edilmiş ek odası kapağı olması durumunda, ilgili noktanın daha yüksek doğrulukta konum bilgisinin üretilmesi için geleneksel yönteme başvurulabilir. Böylece yenilikçi yöntem, geleneksel yöntemin başarımını eniyilemek için kullanılabilir.

Telekomünikasyon firmaları, yeni bölgelerde yatırım yapmadan önce ilgili bölgelerde gerçekleştirdikleri keşif çalışmalarını hızlandırmak için yenilikçi yöntemden yararlanabilir. Böylece ilgili bölge hakkında daha düşük maliyetle ve daha az zaman harcayarak yatırım karar-desteği için genel bir bakış açısı sağlayabilirler. Bu sonuçlara göre daha ayrıntılı çalışma yapılması tercih edilirse geleneksel yöntem kullanılabilir.

Yerel yönetim çalışmaları kapsamında farklı amaçlarla çokça araç kente hizmet etmek için sürekli seyir halindedir. Çöp kamyonları, belediye otobüsleri, zabıta araçları vb. birçok araç işlerini yerine getirirken araç üzerinde bulunan GNSS alıcı entegreli kameralar sürekli görüntü kaydedebilir. Kaydedilen görüntüler bu çalışma kapsamında yararlanılan bilgisayar görü amaçlı derin öğrenme modeline benzer yapay öğrenme modellerinde değerlendirilerek yüzlerce şehir nesnesi görüntüler üzerinden tespit edilip Kent Bilgi Sistemleri ile ilişkilendirilebilir. Akıllı Şehirlerin yoğun olarak tartışıldığı bu günlerde bu tür mekansal zeka uygulamaları yerel yönetimlerin şehirleri daha etkin yönetmesine katkı sağlayacaktır. Aynı zamanda elde edilen ve etiketlenen görüntü veri kümeleri farklı mekansal zeka uygulamaları için etiketli mekansal veri eğitim kümesi altyapısının oluşmasını sağlayacaktır.

\section{Yazar Katkısı}

Ahmet Eğri: Fikir, Tasarım, Literatür Taraması, Veri toplama ve işleme, Yazım. Caner Güney: Analiz ve yorumlama, Denetleme, Yazım, Makale değerlendirme. 


\section{Kaynaklar}

Dellaert, F., Seitz, S. M., Thorpe, C. E., \& Thrun, S. (2000). Structure from motion without correspondence. Proceedings IEEE Conference on Computer Vision and Pattern Recognition. 2, 557-564.

Ertler, C., Mislej, J., Ollmann, T., Porzi, L., Neuhold, G., \& Kuang, Y. (2019). The Mapillary Traffic Sign Dataset for Detection and Classification on a Global Scale. arXiv:1909.04422.

Fawcett, T. (2006). An introduction to ROC analysis. Pattern recognition letters, 27(8), 861-874.

Fischler, M. A., \& Bolles, R. C. (1981). Random sample consensus: a paradigm for model fitting with applications to image analysis and automated cartography. Communications of the ACM, 24(6), 381-395.

Fonstad, M. A., Dietrich, J. T., Courville, B. C., Jensen, J. L., \& Carbonneau, P. E. (2013). Topographic structure from motion: a new development in photogrammetric measurement. Earth surface processes and Landforms, 38(4), 421-430.

Hebbalaguppe, R., Garg, G., Hassan, E., Ghosh, H., \& Verma, A. (2017). Telecom Inventory management via object recognition and localisation on Google Street View Images. 2017 IEEE Winter Conference on Applications of Computer Vision (WACV). 725-733.

Hussain, A., Kazmi, J. H., \& Arsalan, M. H. (2017). Integration of Telecom Databases with Geodatabase Model for The Effective Telecom Network Management Through Geo-Informatics. Journal of Basic and Applied Sciences, 13, 272-280.

Krylov, V. A., Kenny, E., \& Dahyot, R. (2018). Automatic discovery and geotagging of objects from street view imagery. Remote Sensing, 10(5), 661.

Lowe, D. G. (2004). Distinctive image features from scale-invariant keypoints. International journal of computer vision, 60(2), 91-110.

Neuhold, G., Ollmann, T., Rota Bulo, S., \& Kontschieder, P. (2017). The mapillary vistas dataset for semantic understanding of street scenes. Proceedings of the IEEE International Conference on Computer Vision, 4990-4999.

Powers, D.M.W. (2011). Evaluation: From Precision, Recall And F-Measure To ROC, Informedness, Markedness \& Correlation. Journal of Machine Learning Technologies. 2(1), 37-63.

Schonberger, J. L., \& Frahm, J. M. (2016). Structure-from-motion revisited. Proceedings of the IEEE Conference on Computer Vision and Pattern Recognition,4104-4113.

Snavely K.N. (2008). Scene reconstruction and visualization from internet photo collections (Doktora Tezi). University of Washington, Amerika Birleşik Devletleri..

Snavely, N., Seitz, S. M., \& Szeliski, R. (2008). Modeling the world from internet photo collections. International journal of computer vision, 80(2), 189-210.

Tharwat, A. (2018). Classification assessment methods. Applied Computing and Informatics.

Ullman, S. (1979). The interpretation of structure from motion. Proceedings of the Royal Society of London. Series B. Biological Sciences, 203(1153), 405-426.

URL-1: The Economist - European telecoms: In a hole, https://www.economist.com/business/2013/06/29/in-a-hole, (Erişim Tarihi: 26 Ağustos 2019).

URL-2: blog.mapillary.com, (Erişim Tarihi: 6 Ekim 2019).

URL-3: https://www.mapillary.com/project/verification/t9qFVfNh3ltDtiDO2fb2mr, (Erişim Tarihi: 12 Kasım 2019).

URL-4: https://www.mapillary.com/project/verification/t9qFVfNh3ltDtiDO2fb2mr, (Erişim Tarihi: 12 Kasım 2019). 